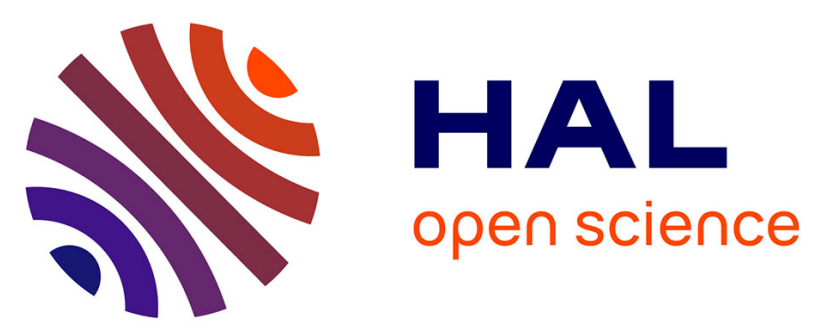

\title{
Synthesis and characterization of $\mathrm{Al} 3+, \mathrm{Cr} 3+, \mathrm{Fe} 3+$ and Ga3+ hydroxyfluorides: correlations between structural features, thermal stability and acidic properties
}

Loïc Francke, Etienne Durand, Alain Demourgues, Alexandre Vimont, Marco Daturi, Alain Tressaud

\section{To cite this version:}

Loïc Francke, Etienne Durand, Alain Demourgues, Alexandre Vimont, Marco Daturi, et al.. Synthesis and characterization of $\mathrm{Al} 3+, \mathrm{Cr} 3+, \mathrm{Fe} 3+$ and $\mathrm{Ga} 3+$ hydroxyfluorides: correlations between structural features, thermal stability and acidic properties. Journal of Materials Chemistry, 2003, 13 (9), pp.23302340. 10.1039/b303535b . hal-00177553

\section{HAL Id: hal-00177553 https://hal.science/hal-00177553}

Submitted on 16 Feb 2016

HAL is a multi-disciplinary open access archive for the deposit and dissemination of scientific research documents, whether they are published or not. The documents may come from teaching and research institutions in France or abroad, or from public or private research centers.
L'archive ouverte pluridisciplinaire HAL, est destinée au dépôt et à la diffusion de documents scientifiques de niveau recherche, publiés ou non, émanant des établissements d'enseignement et de recherche français ou étrangers, des laboratoires publics ou privés. 


\title{
Synthesis and characterization of $\mathrm{Al}^{3+}, \mathrm{Cr}^{3+}, \mathrm{Fe}^{3+}$ and $\mathrm{Ga}^{3+}$ hydroxyfluorides: correlations between structural features, thermal stability and acidic properties
}

\author{
Loïc Francke ${ }^{a}$, Etienne Durand ${ }^{a}$, Alain Demourgues $* a b$, Alexandre Vimont ${ }^{c}$, Marco Daturi $^{c}$ and Alain Tressaud $^{a}$ \\ ${ }^{a}$ Institut de Chimie de la Matière Condensée de Bordeaux-CNRS, 87, avenue du Docteur Albert Schweitzer, 33608, PESSAC Cedex, France. E-mail: \\ demourgues@icmcb.u-bordeaux.fr; Fax: +33-5-40002761; Tel: +33-5-40002655 \\ ${ }^{b}$ Rhodia Recherche CRA, Aubervilliers, France \\ ${ }^{c}$ Laboratoire de Catalyse et Spectrochimie - ENSICaen, Caen, France
}

Received 1st April 2003 , Accepted 30th June 2003

First published on the web 15th July 2003

\begin{abstract}
The synthesis of aluminium, chromium, iron and gallium hydroxyfluorides in their hexagonal tungsten bronze (HTB) $\beta$-form has been undertaken by sol precipitation followed by thermal treatments. These solids, which could be used in heterogeneous catalysis, have been firstly characterized by chemical analysis, X-ray diffraction and FTIR spectroscopy in order to determine their composition and structural features. In the HTB hydroxyfluorides series, there is competition between the formation of M-F and $\mathrm{M}-\mathrm{OH}$ bonds, which depends on the type of cation, the nature of precursor and the route of synthesis. FTIR spectroscopy study has shown the presence of both free- and linked- $\mathrm{OH}^{-}$groups. The nature of cations, the decomposition kinetics of the $\mathrm{M}\left(\mathrm{H}_{2} \mathrm{O}\right)_{6}{ }^{3+}$ aquo-complex and the size of tunnels in the HTB framework account for the thermal stability of these compounds. For instance, a comparison between $\mathrm{Al}^{3+}$ and $\mathrm{Fe}^{3+}$ hydroxyfluorides shows that the $\mathrm{Al}-(\mathrm{F}, \mathrm{OH})$ bond is more stable than the $\mathrm{Fe}-(\mathrm{F}, \mathrm{OH})$ bond, with a
\end{abstract}


difference of more than $200 \mathrm{~K}$ in their thermal stabilities. The substitution of $\mathrm{Fe}^{3+}$ by $\mathrm{Cr}^{3+}$, which gives rise to an increase in the content of $\mathrm{H}_{2} \mathrm{O} / \mathrm{OH}$ groups preferentially around $\mathrm{Cr}^{3+}$, allows the improvement of the $\mathrm{M}-\mathrm{F}$ bonding stability. The template effect of water has also been pointed out. The acidic character of these solids has been evaluated by FTIR analysis using probe molecule adsorption and leads to the conclusion that the strongest Lewis acidity is found in $\mathrm{Al}^{3+}$ and $\mathrm{Ga}^{3+}$ homologous compounds with respect to that of iron hydroxyfluoride. These characteristics can be directly related to the strength of the $\mathrm{M}-(\mathrm{F}, \mathrm{OH})$ chemical bond and the thermal stability of these solids. The use of the ratio $\chi / r^{2}$ between the electronegativity $\chi$ and the ionic radius $r$, which can be ascribed to an electrical field gradient around the cation, has been proposed. This parameter allows a more accurate approach of both the acidic strength and the thermal stability in the hydroxyfluoride series and accounts for the experimentally observed sequence.

\section{Introduction}

Numerous inorganic materials used as acidic heterogeneous catalysts in organic reactions such as alkylation and acylation of aromatic compounds, polymerization and halogen exchange are oxides. The number and strength of Brønsted-Lewis acid sites and the specific area of the materials can often be considered as the key factors for their reaction performances. ${ }_{-1,2}$ Unfortunately, traces of moisture or other proton donors which cannot be excluded in these compounds, contribute to reduction of the catalytic activity. In the case of alumina or aluminium silicate, generally used as Lewis-Brønsted acid catalysts for vapor-phase processes at high temperature, dehydrated aluminium silicate is inactive, for instance in isomerization reactions. Addition of water activates these reactions until a maximum is reached. The control of $\mathrm{OH}^{-} / \mathrm{H}_{2} \mathrm{O}$ groups in acid catalysts thus appears to be a decisive parameter. The incorporation of a more electronegative anion such as a fluoride should increase the activity by enhancing the acidic properties of the catalyst. ${ }_{-}^{3}$

Trivalent aluminium, iron or chromium cations are commonly used in catalysis and are considered as hard acid cations..$_{-7}^{-7}$ Various work relating to inorganic fluorides demonstrated that compounds containing these cations in a fluorinated open framework with 1D tunnels and consequently well defined cleavage planes, possess good catalytic activity in particular in the case of CFC-alternatives. ${ }^{8,9}$ Thus the structural features as well as the acidic character of the involved cations appear to be relevant parameters in the design of new catalysts. The aim of this work is to show the relationships between the nature of cations, the amount of water and hydroxyl groups in the fluorinated framework and the acidic properties as well as the thermal behavior, that both play a key role in the heterogeneous catalysis process.

Firstly, we will present the aluminium, chromium, iron and gallium hydroxyfluoride series and focus on the hexagonal tungsten bronze (HTB) $\beta$-form which exhibits outstanding catalytic properties in accordance with the literature. ${ }^{9-13}$ After a description of the structural and morphological features, the competition between the formation of M-F vs. M-OH bonds and both the role of the involved cation and the synthesis route will be pointed out. Secondly, the thermal stability and the acidic properties will be evaluated and correlated to the structural features of these compounds in order to point out the relevant parameters which can be linked to these properties.

\section{Experimental}




\subsection{Preparation of the $\beta$-forms of trivalent aluminium, iron, chromium and gallium hydroxyfluorides}

Depending on the cation involved, the synthesis was carried out either by thermal degradation of an ammonium metal fluoride $\left(\mathrm{NH}_{4}\right)_{3} \mathrm{MF}_{6} \cdot \delta \mathrm{H}_{2} \mathrm{O}$, or dehydration of a trihydrated trifluoride $\mathrm{MF}_{3} \cdot 3 \mathrm{H}_{2} \mathrm{O}$, but also by fluorination of a hydroxide $\mathrm{M}(\mathrm{OH})_{3} \cdot 3 \mathrm{H}_{2} \mathrm{O}$ under anhydrous $\mathrm{HF}(\mathrm{g})$ followed by heating in a sealed platinum tube. In the case of $\beta-\mathrm{AlF}_{3-x}(\mathrm{OH})_{x} \cdot z \mathrm{H}_{2} \mathrm{O}$ two different routes of synthesis were carried out in order to investigate the role of the pristine material on the structural features, morphology, particle size and thermal behavior of the final aluminium hydroxyfluoride.

Aluminium hydroxyfluoride (route 1). $\beta-\mathrm{AlF}_{3-x}(\mathrm{OH})_{x} \cdot z \mathrm{H}_{2} \mathrm{O}$ was obtained by thermal decomposition of $\left(\mathrm{NH}_{4}\right)_{3} \mathrm{AlF}_{6} \cdot \delta \mathrm{H}_{2} \mathrm{O}$ under a nitrogen flow at $573 \mathrm{~K}$ for 24 hours. The $\left(\mathrm{NH}_{4}\right)_{3} \mathrm{AlF}_{6} \cdot \delta \mathrm{H}_{2} \mathrm{O}$ reactant was prepared by precipitation from an aqueous aluminium(III) nitrate solution. Aluminium(III) nitrate nanohydrate was dissolved in a large amount of water. An overstoichoimetric aqueous solution $\mathrm{NH}_{4} \mathrm{OH}-\mathrm{HF}=2: 1$ was then slowly added, in order to keep the medium basic. After 14 hours at room temperature, the white precipitate was filtered, washed with a large amount of water and dried for one night at $363 \mathrm{~K}$.

Aluminium hydroxyfluoride (route 2). HTB aluminium hydroxyfluoride was also obtained by thermal dehydration of $\mathrm{AlF}_{3} \cdot 3 \mathrm{H}_{2} \mathrm{O}$, a synthesis proposed by Le Bail et al. ${ }_{-}^{14}$ The starting compound $\mathrm{AlF}_{3} \cdot 3 \mathrm{H}_{2} \mathrm{O}$ was prepared from an alcoholic aluminium(III) nitrate solution. An alcoholic solution was used in order to favor the precipitation of $\mathrm{AlF}_{3} \cdot 3 \mathrm{H}_{2} \mathrm{O}$ which is less soluble in ethanol than in water. Aluminium(III) nitrate nanohydrate was dissolved in a large amount of ethanol-water $=7$ : 3 solution. A stoichiometric aqueous solution of HF was slowly added. The precipitate was filtered, washed with a large amount of water and ethanol, and dried overnight at $363 \mathrm{~K}$. $\beta-\mathrm{AlF}_{3}$ was then obtained by dehydration of $\mathrm{AlF}_{3} \cdot 3 \mathrm{H}_{2} \mathrm{O}$ under vacuum at $493 \mathrm{~K}$ during 5 hours followed by thermal treatment under an argon atmosphere for 14 hours at $723 \mathrm{~K}$.

Iron and iron-chromium hydroxyfluorides. $\beta-\mathrm{FeF}_{3-x}(\mathrm{OH})_{x} \cdot z \mathrm{H}_{2} \mathrm{O}$ and $\beta-\mathrm{Fe}_{1-x} \mathrm{Cr}_{x} \mathrm{~F}_{3-y}(\mathrm{OH})_{y} \cdot z \mathrm{H}_{2} \mathrm{O}(x=0.1$ and 0.2$)$ were prepared from their homologous trihydrated fluorides, under a "self-generated" atmosphere 15 at $493 \mathrm{~K}$ for 16 hours. The starting material $\mathrm{FeF}_{3} \cdot 3 \mathrm{H}_{2} \mathrm{O}$ was obtained from an alcoholic iron(III) nitrate solution, as described above. The reactant $\mathrm{Fe}_{1-x} \mathrm{Cr}_{x} \mathrm{~F}_{3} \cdot 3 \mathrm{H}_{2} \mathrm{O}$ was prepared by dissolving nanohydrated nitrates exhibiting various $\mathrm{Fe}$ III $: \mathrm{CrIII}$ ratios in an ethanol-water $=7: 3$ solution. However, in order to obtain pure $\mathrm{Fe}_{1-x} \mathrm{Cr}_{x} \mathrm{~F}_{3} \cdot 3 \mathrm{H}_{2} \mathrm{O}$, the reaction mixture was heated at $363 \mathrm{~K}$ over a 14 hour flow back. For compositions with $x>0.2$, a phase separation between iron and chromium hydroxyfluorides occurred.

Chromium hydroxyfluoride. Due to the tendency of chromium salts to form pyrochlore hydroxyfluoride phases, ${ }_{-}^{16}$ a CrIII-based HTB phase could not be synthesized by thermal dehydration of $\mathrm{CrF}_{3} \cdot 3 \mathrm{H}_{2} \mathrm{O} \cdot \underline{14,17}$ The best route was the thermal decomposition of $\left(\mathrm{NH}_{4}\right)_{3} \mathrm{CrF}_{6} \cdot \delta \mathrm{H}_{2} \mathrm{O}$ under a "self-generated" atmosphere. -15 Moreover, in order to avoid the presence of any ammonium group which would generate basic properties in the final material, another route was developed. $\mathrm{Cr}(\mathrm{OH})_{3} \cdot 3 \mathrm{H}_{2} \mathrm{O}$ reactant was prepared by precipitation from an aqueous chromium(III) nitrate solution. Chromium(III) nitrate nanohydrate was dissolved in a large amount of water. A stoichiometric amount of a $30 \% \mathrm{NH}_{4} \mathrm{OH}$ aqueous solution was then slowly added. The green precipitate was filtered, washed with a large amount of water and dried overnight at $363 \mathrm{~K}$. The chromium(III) trihydrated hydroxide was then dehydrated at $373 \mathrm{~K}$ during 14 hours under an argon flow and then fluorinated under an anhydrous HF flow at $323 \mathrm{~K}$ for 8 hours. The as-prepared amorphous solid was then placed in a platinum tube sealed under an argon atmosphere and was heated at $498 \mathrm{~K}$ for 16 hours. In this process, the ammonium content remained smaller than in the case of the thermal decomposition of $\left(\mathrm{NH}_{4}\right)_{3} \mathrm{CrF}_{6}$. For both these routes the ammonium amount remained small and about $1 \%$ in mass.

Gallium hydroxyfluoride. HTB gallium hydroxyfluoride was prepared by the method of Beck et al. ${ }_{-}^{18}$ Pure gallium hydroxyfluoride was obtained by thermal decomposition of $\left(\mathrm{NH}_{4}\right)_{3} \mathrm{GaF}_{6} \cdot \delta \mathrm{H}_{2} \mathrm{O}$ under a nitrogen flow at $693 \mathrm{~K}$ for 14 hours. The synthesis from trihydrated gallium fluoride was not pursued because of the 

occurrence of impurities in the final product.

\subsection{Fluorine analysis by the Seel method}

The amount of $\mathrm{F}^{-}$anions in the $\mathrm{HTB}$ compounds has been determined by the Seel method. ${ }_{-}^{19}$ The samples were first dissolved in $\mathrm{K}_{2} \mathrm{CO}_{3}-\mathrm{Na}_{2} \mathrm{CO}_{3}$ in a platinum boat. The molten solution was cooled down to room temperature and dissolved in a small amount of distilled water. About $1 \mathrm{~g}$ of silica and $20 \mathrm{ml}$ of $98 \% \mathrm{H}_{2} \mathrm{SO}_{4}$ were slowly added to the solution. This solution was then distillated under a water vapor flow at $523 \mathrm{~K}$ in order to favor the formation of $\mathrm{H}_{2} \mathrm{SiF}_{6}$ and its evaporation. $\mathrm{H}_{2} \mathrm{SiF}_{6}$ was condensed and the fluorine content was determined with an $\mathrm{F}^{-}$specific electrode. The poor solubility of iron compounds did not enable any estimation of their $\mathrm{F}^{-}$content. $\mathrm{NaF}, \mathrm{NH}_{4} \mathrm{~F}$ and $\alpha-\mathrm{AlF}_{3}$ fluorides were used as standards.

\subsection{X-Ray diffraction and scanning electron microscopy study}

The different reactants and HTB phases were characterized by X-ray powder diffraction. Powder diffraction patterns were recorded at room temperature on a Philips PW diffractometer in Bragg-Brentano geometry, using graphite-monochromated CuK $\alpha$ radiation. The $2 \theta$ range was $5-60^{\circ}$, with a step of $0.02^{\circ}$; the counting time was $25 \mathrm{~s}$. The coherence domains were calculated from the X-ray diffraction patterns on the basis of the Scherrer method. SEM pictures were obtained with a FX 600 microscope. Surface charge elimination was achieved by gold deposition.

\subsection{Thermogravimetric analysis}

The thermal degradation of the different compounds was followed by a thermogravimetric analyzer (Setaram TAG 24) coupled with a quadripolar mass spectrometer (Balzers Thermostar) which allowed the detection of HF and water departure. Each sample was heated under an argon atmosphere (heating rate $1 \mathrm{~K}$ min ${ }^{-1}$ ) until HF was detected by mass spectrometry, leading to the decomposition of the hydroxyfluoride. The departure of water and hydroxyl groups starts before the fluorine species evolution.

\subsection{Surface area and particle size studies}

All compounds were characterized by the BET method in order to determine their surface area. The different HTB hydroxyfluorides were first heated at $373 \mathrm{~K}$ under vacuum. $\mathrm{N}_{2}$ was used at $77 \mathrm{~K}$. A Mastersizer 2000 particles analyzer, double laser scattering, was used to investigate the various distributions of particle size in all HTB phases. The samples were dispersed in distillated water under ultrasonics during 5 minutes.

\subsection{FTIR spectroscopy: localization and nature of hydroxide groups by probe molecule adsorption}

The localization of hydroxyl groups was determined by an FTIR study of the adsorption of pyridine $\mathrm{C}_{5} \mathrm{H}_{5} \mathrm{~N}$, heavy tertiobutanol $\left(\mathrm{C}_{3} \mathrm{H}_{9}\right) \mathrm{C}(\mathrm{OD})$, heavy water $\mathrm{D}_{2} \mathrm{O}$, and dideuterium $\mathrm{D}_{2}$ on the different samples. Because of the various size of these molecules, the variation of the magnitude of OH bands accounts for the localization of 
hydroxyl groups. The presence of characteristic IR bands of pyridine adsorbed on the surface of the different samples provides information not only on the nature of acid sites but also on the strength and the amount of both Lewis and Brønsted acid sites. ${ }_{-}^{20}$ Powdered samples ( $\approx 20$ mg) were pressed into self-supported wafers of about $10 \mathrm{mg} \mathrm{cm}^{-2}$, and were activated in situ in a quartz cell connected to a high vacuum system $\left(10^{-4} \mathrm{~Pa}\right)$ and placed into the IR beam. The procedure started with a 2 hour treatment under vacuum at $573 \mathrm{~K}$ for AlIII compounds and $473 \mathrm{~K}$ and $373 \mathrm{~K}$ for FeIII and $\mathrm{Cr}^{\mathrm{III}}$ samples respectively, i.e. before the HF departure and the consequent decomposition of the sample. The spectrum of the outgassed sample, that is the so-called "activated" sample, was recorded at room temperature. Spectra were recorded on a Nicolet Magna 750 spectrophotometer, equipped with a MCT detector and an extended KBr beamsplitter. Different temperatures were chosen in order to investigate the presence of water, isolated $\mathrm{OH}$ groups, or linked $\mathrm{OH}$ groups and the influence of these groups in the thermal stability of $\mathrm{HTB}$ hydroxyfluorides.

\section{Results}

The X-ray diffraction patterns for the various HTB-hydroxyfluorides have been represented in Fig. 1. Cell parameters were calculated from these diffractograms by a whole pattern fitting method on the basis of the orthorhombic $(\mathrm{Cmcm})$ space group proposed in the literature_- and are collected in Table 1 [Note that in the following tables and text, simplified formulations " $\beta$ - $M(\mathrm{OH}, \mathrm{F})_{3}$ " may stand instead of $\mathrm{MF}_{3-x}(\mathrm{OH})_{x}, \mathrm{H}_{2} \mathrm{O} \beta$-hydroxyfluorides]. The type of preparation route of $\mathrm{HTB}$ aluminium hydroxyfluoride does not really affect the cell parameters and the two $\beta-\mathrm{AlF}_{3-x}(\mathrm{OH})_{x} \cdot z \mathrm{H}_{2} \mathrm{O}$ phases exhibit similar unit cell parameters and cell volumes. In the case of $\beta-\mathrm{AlF}_{3}$, the hexagonal tunnels had been shown to be about $2.42 \AA$ wide, ${ }_{-}^{14}$ and about $2.70 \AA$ wide in the case $\beta-\mathrm{FeF} \cdot 0.33 \mathrm{H}_{2} \mathrm{O} .{ }_{-}^{21}$ In the case of mixed iron-chromium HTB hydroxyfluorides, the cell volume follows Vegard's law in good agreement with the respective amounts of trivalent iron and chromium ions.

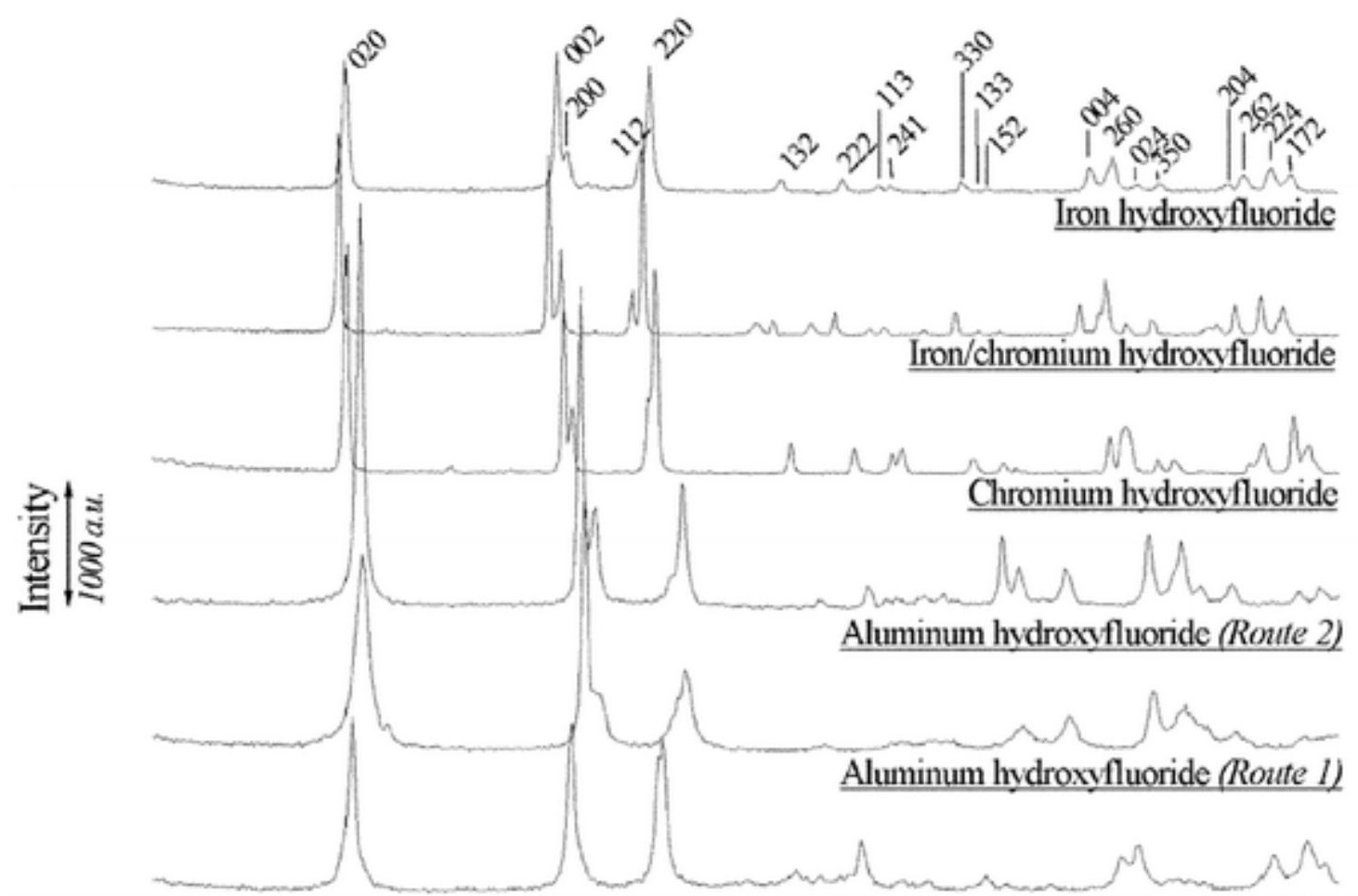




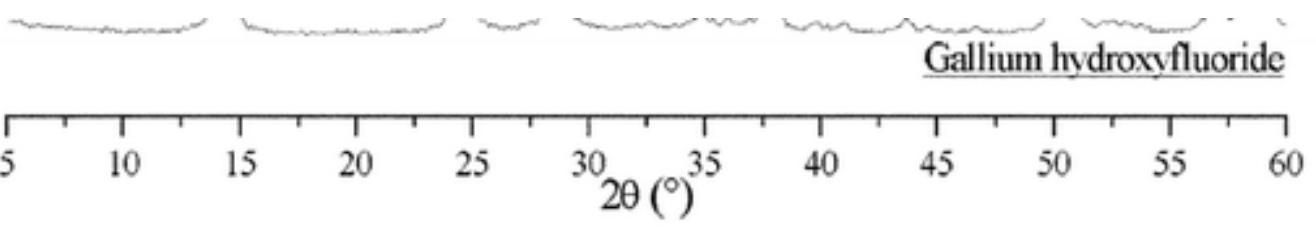

Fig. 1 X-Ray diffraction patterns of the different HTB hydroxyfluorides.

Table 1 Unit-cell parameters of the different HTB hydroxyfluorides calculated from XRD powder patterns $\underline{\underline{a}}$

\begin{tabular}{|c|c|c|c|c|c|}
\hline HTB hydroxyfluorides & $a / \AA ̊$ & $b / \AA$ & $c / \AA ̊$ & Cell volume $/ \AA^{3}$ & $\begin{array}{l}\text { Average crystallite size } \\
\text { determined from } X \text {-ray } \\
\text { diffraction patterns } \frac{b}{\AA}\end{array}$ \\
\hline “ $\beta-\mathrm{Al}(\mathrm{OH}, \mathrm{F})_{3}$ ” routel & $6.864(9)$ & $12.047(1)$ & $7.100(2)$ & 587.10 & 122 \\
\hline " $\beta$ - $\mathrm{Al}(\mathrm{OH}, \mathrm{F})_{3}$ " route 2 & $6.873(4)$ & $12.023(5)$ & $7.109(2)$ & 587.45 & 239 \\
\hline$" \beta-\mathrm{Fe}(\mathrm{OH}, \mathrm{F})_{3} "$ & $7.413(5)($ & $12.746(2)$ & $7.527(1)$ & 711.17 & 279 \\
\hline$" \beta-\mathrm{Fe}_{0.8} \mathrm{Cr}_{0.2}(\mathrm{OH}, \mathrm{F})_{3} "$ & $7.379(8)$ & $12.754(2)$ & $7.505(1)$ & 706.27 & 330 \\
\hline$" \beta-\mathrm{Cr}(\mathrm{OH}, \mathrm{F})_{3} "$ & $7.255(2)$ & $12.546(7)$ & $7.372(7)$ & 671.28 & 354 \\
\hline$" \beta-\mathrm{Ga}(\mathrm{OH}, \mathrm{F})_{3} "$ & $7.123(2)$ & $12.378(4)$ & 7.261(3) & 640.19 & 218 \\
\hline
\end{tabular}

The coherence domains, estimated from X-ray diffraction patterns (Table 1), are different, depending on the cation and the chosen route. This information should be compared to SEM micrographs (Fig. 2), BET surface area results, and particle size distribution analysis (Figs 3 and 4). HTB chromium hydroxyfluoride has a wide size distribution (Fig. 3-a), between $0.3 \mu \mathrm{m}$ and $80 \mu \mathrm{m}$, the peak around $800 \mu \mathrm{m}$ probably being the result of an agglomeration of many particles which have not been singled by ultrasonics. SEM micrographs (Fig. 2-a) as well as granulometry analysis show a heterogeneity of particles size of $\beta-\mathrm{CrF} F_{3-x}(\mathrm{OH})_{x} \cdot z \mathrm{H}_{2} \mathrm{O}$. In iron hydroxyfluoride compounds a more homogeneous distribution of the particles size is found (Fig. 3-b) in good agreement with SEM results (Fig. 2-b). However one has to note an agglomeration of thin particles when a small proportion of trivalent iron is substituted by trivalent chromium, as in $\beta-\mathrm{Fe}_{0.8} \mathrm{Cr}_{0.2} \mathrm{~F}_{3-x}(\mathrm{OH})_{x} \cdot z \mathrm{H}_{2} \mathrm{O}(\mathrm{Fig}$. $\underline{2}-\mathrm{c})$. Consequently the average particle size appears at higher values. Aluminium hydroxyfluoride shows the most narrow size distribution and the most homogeneous particle size. $\beta-\mathrm{AlF}_{3-x}(\mathrm{OH})_{x} \cdot z \mathrm{H}_{2} \mathrm{O}$ prepared by route 1 has the smallest particle size and the highest surface area whereas route 2 yields larger crystals than route 1 with a smaller surface area. Such a difference between the two different routes is also evidenced from the average particle size: about $5 \mu \mathrm{m}$ for route 1 (Fig. 3-d) and about $35 \mu \mathrm{m}$ for route 2 (Fig. 3-e). 


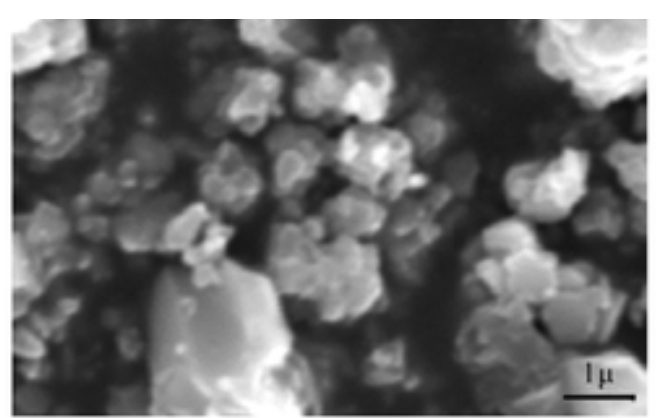

a- Chromium hydroxyfluoride.

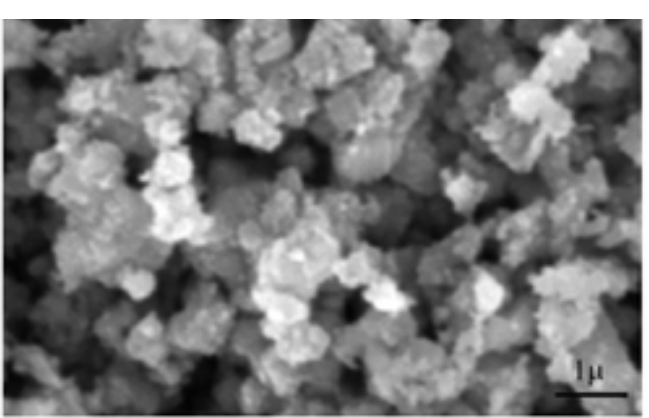

$b$ - Iron hydroxyfluoride.

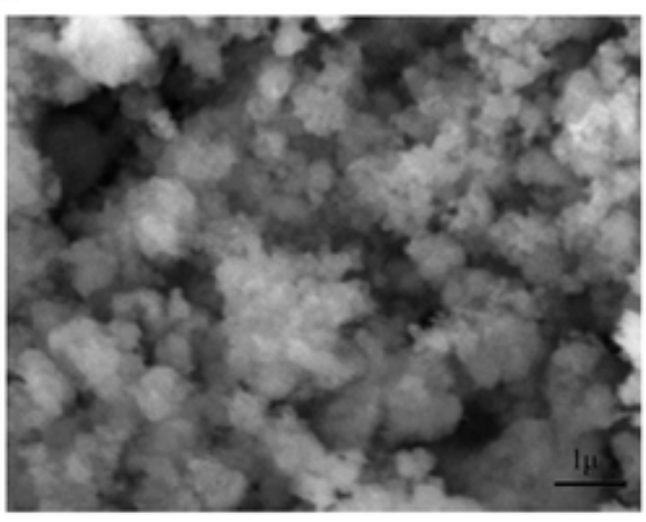

c- Iron/chromium hydroxyfluoride.

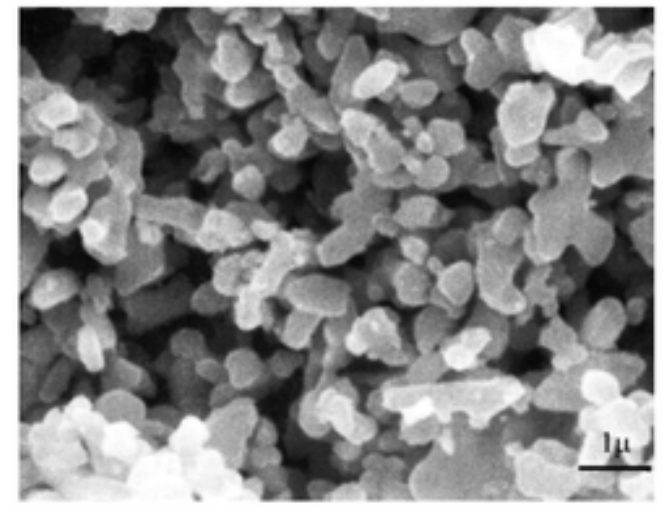

d-Alumimum hydroxyfluoride Route 1 .

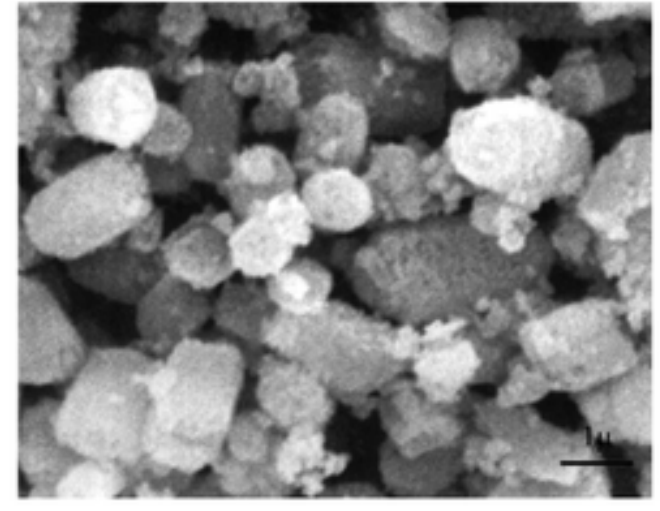

e- Aluminum hydroxyfluoride Route 2.

Fig. 2 SEM pictures of HTB hydroxyfluorides.

$\mathrm{O}$

L

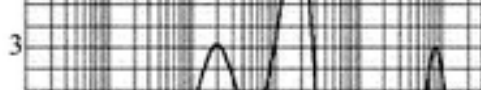

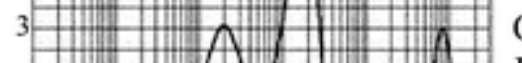

V

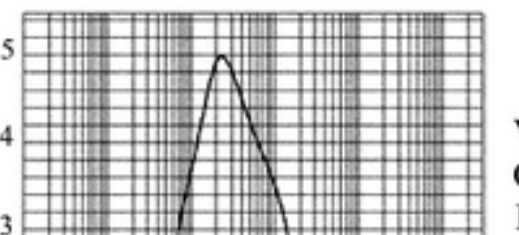

$\mathrm{V}$

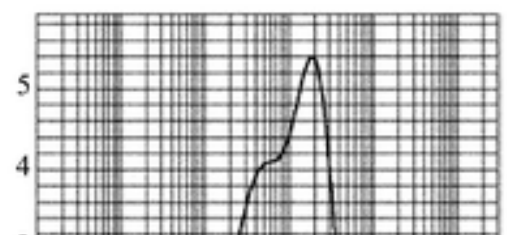


$\mathrm{u}$
$\mathrm{M}$
$\mathrm{E}$
$(\%)$ $\begin{array}{llllll}0.01 & 0.1 & 1 & 10 & 100 & 1000\end{array}$ Particle size $(\mu \mathrm{m})$
)

${ }_{0}^{1}$

0.01

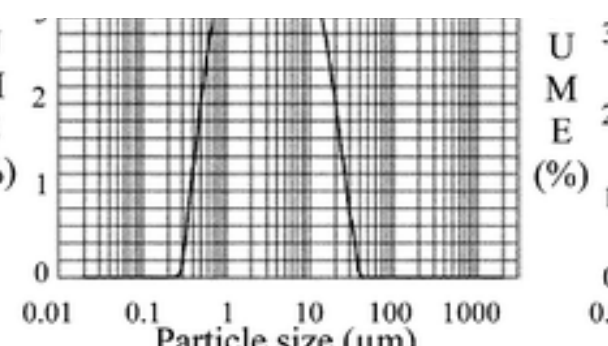

3

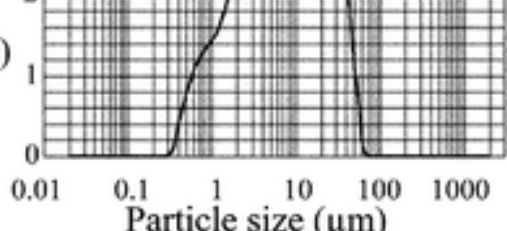

a- Chromium hydroxyfluoride.

b-Iron Hydroxyfluoride.

c-Iron/chromium hydroxyfluoride.
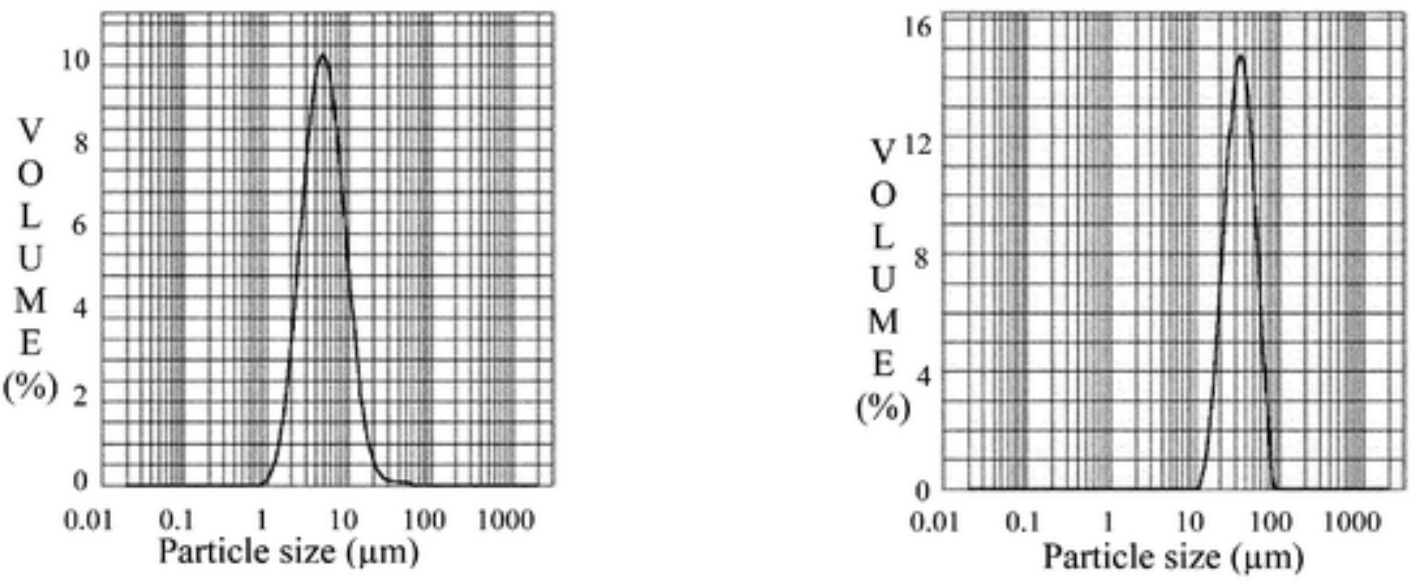

d-Aluminum hydroxyfluoride Route 1.

e-Aluminum hydroxyfluoride Route 2.

Fig. 3 Particle size distribution obtained from double laser scattering patterns.

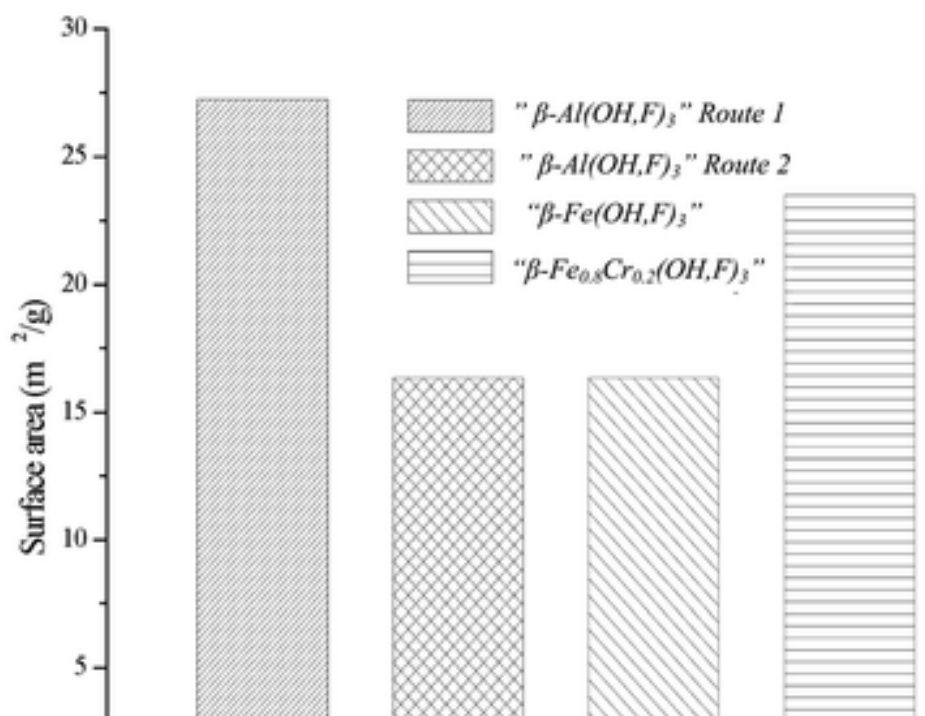




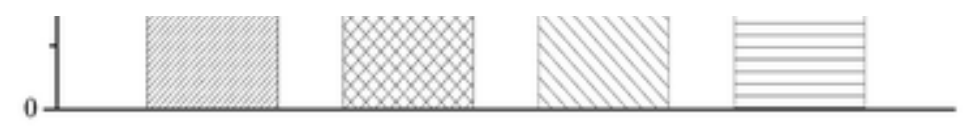

Fig. 4 Surface area of HTB hydroxyfluorides measured by BET method.

The estimation of the amount of $\mathrm{F}^{-}$in different samples is reported in Table 2. As previously quoted, it was not possible to dissolve the samples containing iron. Commercial $\alpha-\mathrm{AlF}_{3}$ exhibits a high concentration of fluoride anions but the estimation of the amount of $\mathrm{F}^{-}$leads to consideration of the presence of hydroxyl groups. In fact, the formula of the product should be written $\mathrm{AlF}_{2.8}(\mathrm{OH})_{0.2}$. The presence of these hydroxyl groups in the commercial product reveals the competition between $\mathrm{M}-\mathrm{OH}$ and $\mathrm{M}-\mathrm{F}$ bonding. Moreover, both $\beta-\mathrm{AlF}_{3-x}(\mathrm{OH})_{x} \cdot z \mathrm{H}_{2} \mathrm{O}$ and $\beta-\mathrm{CrF}_{3-x}(\mathrm{OH})_{x} \cdot z \mathrm{H}_{2} \mathrm{O}$ compounds do not exhibit the expected amount of $\mathrm{F}^{-}$anion for a $\mathrm{MF}{ }_{3}$ formulation. There is an additional difference in the composition of the two aluminium hydroxyfluorides. Route 2 leads to a more fluorinated aluminium hydroxyfluoride than route 1 . An estimation of the compositions (Table 2) can then be proposed by considering the total water departure during the thermogravimetric analysis, i.e. $\mathrm{AlF}_{1.95}(\mathrm{OH})_{1.05} \cdot 0.53 \mathrm{H}_{2} \mathrm{O}$ for route 1 and $\mathrm{AlF}_{2.20}(\mathrm{OH})_{0.80} \cdot 0.29 \mathrm{H}_{2} \mathrm{O}$ for route 2 . In any case, the amount of hydroxyl groups and water remains high. As far as the chromium compound is concerned, both the fluorine analysis and the TGA measurements show that the amount of water as well as hydroxyl groups is the highest. Moreover the departure of fluorine species occurs simultaneously with water and hydroxyls, which avoids any determination of the chemical composition.

Table 2 Determination of F amount in aluminium(III) and chromium(III) HTB hydroxyfluorides

\begin{tabular}{|c|c|c|c|}
\hline HTB hydroxyfluorides & $\begin{array}{l}\text { F elemental analysis }{ }^{a} \\
\text { (weight } \% \text { ) }\end{array}$ & $\begin{array}{l}\text { Calculated } \mathrm{F} \text { amount (weight } \\
\% \text { ) for } \mathrm{MF}_{3} \text { formulation }\end{array}$ & $\begin{array}{l}\text { Chemical formulas deduced from } \\
\text { thermogravimetry }\end{array}$ \\
\hline$\alpha-\mathrm{AlF}_{3}($ commercial) & 63.55 & 67.87 & $\mathrm{AlF}_{2.8}(\mathrm{OH})_{0.2}$ \\
\hline " $\beta$-Al $(\mathrm{OH}, \mathrm{F})_{3} "$ Route 1 & 45.34 & 67.87 & $\mathrm{AlF}_{1.95}(\mathrm{OH})_{1.05}, 0.53 \mathrm{H}_{2} \mathrm{O}$ \\
\hline " $\beta$-Al $(\mathrm{OH}, \mathrm{F})_{3}$ " Route 2 & 51.01 & 67.87 & $\mathrm{AlF}_{2.20}(\mathrm{OH})_{0.80}, 0.29 \mathrm{H}_{2} \mathrm{O}$ \\
\hline$" \beta-\mathrm{Cr}(\mathrm{OH}, \mathrm{F})_{3} "$ & 37.51 & 52.29 & - \\
\hline
\end{tabular}

The FTIR technique is able to give important information on the presence of hydroxyl groups in the network and to define the nature and localization of these OH groups. Various types of $\mathrm{OH}$ groups can be found according to the nature of their nearest neighbors (Fig. 5). On one hand, when a hydroxyl has no other hydroxyl groups, water molecules, ammonia or organics containing protons as nearest neighbors, it is called an isolated OH group. On the other hand a substituting OH group can be in interaction with other surrounding $\mathrm{OH}$ groups or impurities: in this latter case, such $\mathrm{OH}$ groups are called linked $\mathrm{OH}$ groups, and the band assigned to hydroxyl groups in the FTIR spectra becomes broader and moves to lower wavenumbers. The absorption bands assigned to $v(\mathrm{OH})$ vibrations of the hydroxyl groups present on the surface after sample activation, i.e. removal of physisorbed water, are observed in the 4000-3000 $\mathrm{cm}^{-1} \mathrm{range}$ of the IR spectra (Fig. 6).

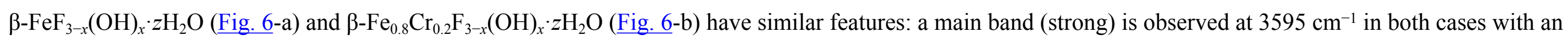
asymmetric tail toward lower wavenumbers. A shoulder is detected at $3572 \mathrm{~cm}^{-1}$ for $\beta-\mathrm{Fe}_{0.8} \mathrm{Cr}_{0.2} \mathrm{~F}_{3-x}(\mathrm{OH})_{x} \cdot z \mathrm{H}_{2} \mathrm{O}$. The position and the reduced $\mathrm{FWHM}$ of these bands 


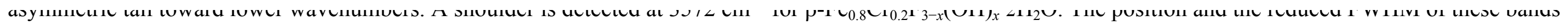

accounts for the presence of isolated $\mathrm{OH}$ groups, i.e. without $\mathrm{H}$-bonding interactions with neighboring $\mathrm{OH}$ groups. However the occurrence of another broad band at lower wavenumbers $\left(3505 \mathrm{~cm}^{-1}\right.$ and $3520 \mathrm{~cm}^{-1}$ respectively) reveals the presence of linked hydroxyls $(\underline{F i g} .5-b)$. In the case of $\beta-\mathrm{AlF}{ }_{3-x}(\mathrm{OH})_{x} \cdot z \mathrm{H}_{2} \mathrm{O}$ prepared by route

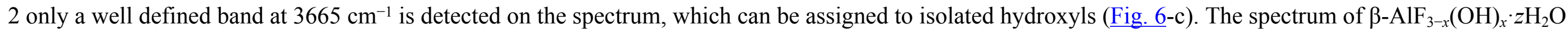
synthesized by route 1 (Fig. 6-d) is clearly different: three well defined bands are noticeable at $3700 \mathrm{~cm}^{-1}, 3680 \mathrm{~cm}^{-1}$ and $3665 \mathrm{~cm}^{-1}$. All these features can be assigned to isolated $\mathrm{OH}$ groups. The spectrum of $\mathrm{CrF}_{3}$ has not been presented here since, after evacuation at $373 \mathrm{~K}$, the amount of adsorbed water on the surface is still too important, and $v(\mathrm{OH})$ features remain hidden.

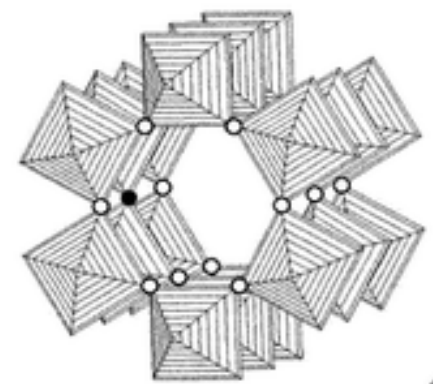

a) Free-hydroxyl group

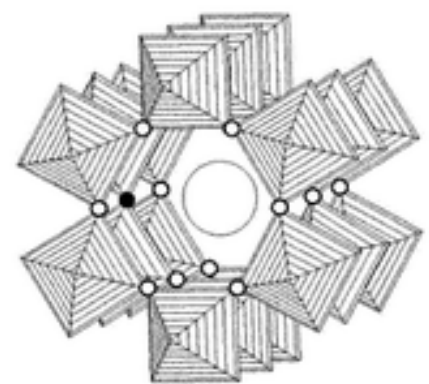

c) Linked-hydroxyl group with water or ammonia.
Arbitrary scales.

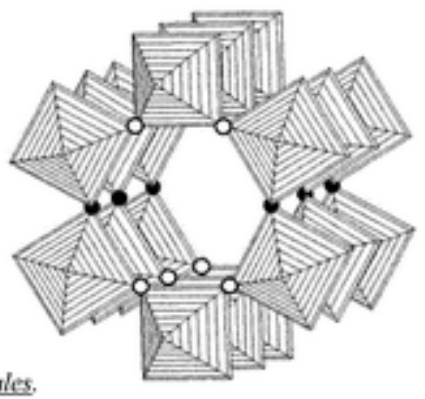

b) Linked-hydroxyl groups

- $\mathrm{OH}$

F

Water or ammonia

Fig. 5 Environments around hydroxyl groups in HTB tunnels.

3,2
3,0
2,8
2,6
2,4
2,2 $\quad\left[\begin{array}{l}3595 \\ \text { (a) outgassed } \\ \text { (b) Probed by }\left(\mathrm{C}_{3} \mathrm{H}_{9}\right) \mathrm{C} \text {-OD } \\ \text { (c) Probed by } \mathrm{D}_{2} \mathrm{O} \\ 3505 \\ 1\end{array}\right.$

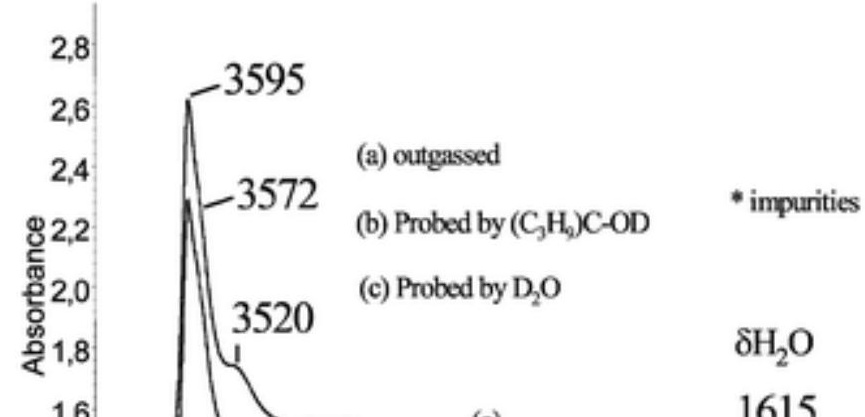




\section{e- Aluminum hydroxyfluoride Route 2 (extended scale). f- $\alpha \mathrm{AlF}_{3}$ outgassed at $573 \mathrm{~K}$}

Fig. 6 FTIR spectroscopy: nature and localization of hydroxyl groups in HTB

hydroxyfluorides by probe molecule adsorption; the water contribution for iron-based compounds is given in the $1400-1800 \mathrm{~cm}^{-1}$ range.

FTIR spectroscopy is a technique very sensitive to isotopic exchange. The localization of hydroxyl groups can be determined using H-D exchange capacity with deuterium donor compounds having various molecular sizes: deuterated tertiobutanol $\left(\mathrm{C}_{3} \mathrm{H}_{9}\right) \mathrm{C}(\mathrm{OD})$, heavy water $\mathrm{D}_{2} \mathrm{O}$, and dideuterium $\mathrm{D}_{2}$. A resume of tunnel accessibility determined by deuterated sample molecules is presented in Table 3 . After $\left(\mathrm{C}_{3} \mathrm{H}_{9}\right) \mathrm{C}(\mathrm{OD})$ exchange on $\beta-\mathrm{FeF}{ }_{3-x}(\mathrm{OH})_{x} \cdot z \mathrm{H}_{2} \mathrm{O}(\underline{\mathrm{Fig}} \cdot \mathbf{6}-\mathrm{a})$ and $\beta-\mathrm{Fe}_{0.8} \mathrm{Cr}_{0.2} \mathrm{~F}_{3-x}(\mathrm{OH})_{x} \cdot z \mathrm{H}_{2} \mathrm{O}$ ( Fig. 6-b), no significative modification of the $\mathrm{OH}$ bands was observed whatever the sample, suggesting that hydroxyl groups were not localized on the external surface of the crystallites. However, after $\mathrm{D}_{2} \mathrm{O}$ exchange on $\beta-\mathrm{FeF}_{3-x}(\mathrm{OH})_{x} \cdot z \mathrm{H}_{2} \mathrm{O}$ and $\beta-\mathrm{Fe}_{0.8} \mathrm{Cr}_{0.2} \mathrm{~F}_{3-x}(\mathrm{OH})_{x} \cdot z \mathrm{H}_{2} \mathrm{O}$, the $\mathrm{OH}$ bands have strongly decreased and new OD bands corresponding to the exchanged hydroxyls are clearly observed between 2700 and $2600 \mathrm{~cm}^{-1}$. The fact that the $\mathrm{H}-\mathrm{D}$ exchange is impeached in the case of deuterated alcohol, but is allowed for heavy water, is interpreted as a consequence of the steric effect of the molecules: the diameter of the tunnels is too small to allow the diffusion of tertiobutanol inside the material. Therefore we conclude that the hydroxyl groups which are accessible to $\mathrm{D}_{2} \mathrm{O}$ but not to $\left(\mathrm{C}_{3} \mathrm{H}_{9}\right) \mathrm{C}(\mathrm{OD})$ are localized into the tunnels. After pyridine adsorption on $\beta-\mathrm{AlF}_{3-x}(\mathrm{OH})_{x} \cdot z \mathrm{H}_{2} \mathrm{O}$ prepared by route 1 (Fig. 6 - $\mathrm{d}$ ), the FTIR bands of the two stronger free hydroxyl groups ( 3700 and $3680 \mathrm{~cm}^{-1}$ ) decrease, suggesting that these two free $\mathrm{OH}$ groups are localized on the surface of the material. However neither the third type of free hydroxyl groups $\left(3665 \mathrm{~cm}^{-1}\right)$ nor the linked $\mathrm{OH}$ groups $\left(3560 \mathrm{~cm}^{-1}\right)$ are affected by pyridine adsorption: these hydroxyl groups should thus be localized into the HTB tunnels. For $\beta-\mathrm{AlF}_{3-x}(\mathrm{OH})_{x} \cdot z \mathrm{H}_{2} \mathrm{O}$ prepared by route 2 , the free-OH band is not affected by adsorption of pyridine nor by addition of $\mathrm{D}_{2} \mathrm{O}$, which demonstrates that these $\mathrm{OH}$ groups are not localized onto the surface (Fig. 6-c, e). However, after $\mathrm{D}_{2}$ treatment, $40 \%$ of these hydroxyl groups can be reached by $\mathrm{D}_{2}$. The partial accessibility by $\mathrm{D}_{2}$ could be due to the presence of residual water molecules or impurities into the tunnels (broad bands at about $3000 \mathrm{~cm}^{-1}$ and two others at $c a 1600$ and $\left.1570 \mathrm{~cm}^{-1}\right)$. It did not appear necessary to study $\beta-\mathrm{AlF}_{3-x}(\mathrm{OH})_{x} \cdot z \mathrm{H}_{2} \mathrm{O}$ prepared by route 1 using deuterated molecules because pyridine adsorption revealed the occurrence of two additional kinds of hydroxyl groups located at the surface.

Table 3 Molecular volume of probe molecules and tunnel diameter in aluminium and iron HTB fluorides at different crystallographic sites

\begin{tabular}{|c|c|c|c|c|c|}
\hline \multirow[b]{2}{*}{ Probe molecule } & \multirow[b]{2}{*}{ Volume $/ \mathbf{n m}^{\mathbf{3}}$} & \multicolumn{4}{|c|}{ Tunnel diameter in HTB structure/nm } \\
\hline & & $\mathbf{A l F}_{3}{ }^{14}$ & & $\mathrm{FeF}_{3} \cdot \mathbf{0}$ & \\
\hline $\mathrm{C}_{5} \mathrm{H}_{5} \mathrm{~N}$ & 0.146 & $(0,0,0)$ & $(0,0,1 / 4)$ & $(0,0,0)$ & $(0,0,1 / 4)$ \\
\hline$\left(\mathrm{C}_{3} \mathrm{H}_{9}\right) \mathrm{C}(\mathrm{OD})$ & 0.173 & & & & \\
\hline $\mathrm{D}_{2} \mathrm{O}$ & 0.032 & 0.242 & 0.330 & 0.270 & 0.360 \\
\hline $\mathrm{D}_{2}$ & 0.026 & & & & \\
\hline
\end{tabular}


The thermal stability regarding fluorine departure is quite different for $\mathrm{HTB}^{3+}, \mathrm{Cr}^{3+}, \mathrm{Fe}^{3+}$ or $\mathrm{Ga}^{3+}$ hydroxyfluorides. Fig. 7 shows the ion current corresponding to mass $m=19(\mathrm{~F})$, which is indeed correlated to the departure of HF, as deduced from mass spectrometry experiments carried out during the thermogravimetric analysis of the different compounds under an argon atmosphere. It can be noted that the mechanisms of thermal decomposition of the HTB phases have been previously investigated. 22 The $\beta-\mathrm{CrF}_{3-x}(\mathrm{OH})_{x} \cdot z \mathrm{H}_{2} \mathrm{O}$ is the most unstable compound, fluorine departure starting from $393 \mathrm{~K}$. The $\beta-\mathrm{FeF}{ }_{3-x}(\mathrm{OH})_{x} \cdot z \mathrm{H}_{2} \mathrm{O}$ is stable up to $473 \mathrm{~K}$ whereas gallium and aluminium hydroxyfluorides are largely more stable. In the case of aluminium hydroxyfluoride prepared by route 1 , fluorine evolution starts above $563 \mathrm{~K}$ and above $650 \mathrm{~K}$ in the case of $\beta-\mathrm{AlF}_{3-x}(\mathrm{OH})_{x} \cdot z \mathrm{H}_{2} \mathrm{O}$ prepared by route 2 . In both cases, the decomposition leads to the formation of rhombohedral $\mathrm{AlF}_{3}$. The addition of a small amount of trivalent chromium in HTB iron hydroxyfluoride increases its thermal stability to $493 \mathrm{~K}$. In this latter case, it is relevant to note that this compound also has a surface area higher than a pure homologous iron compound.

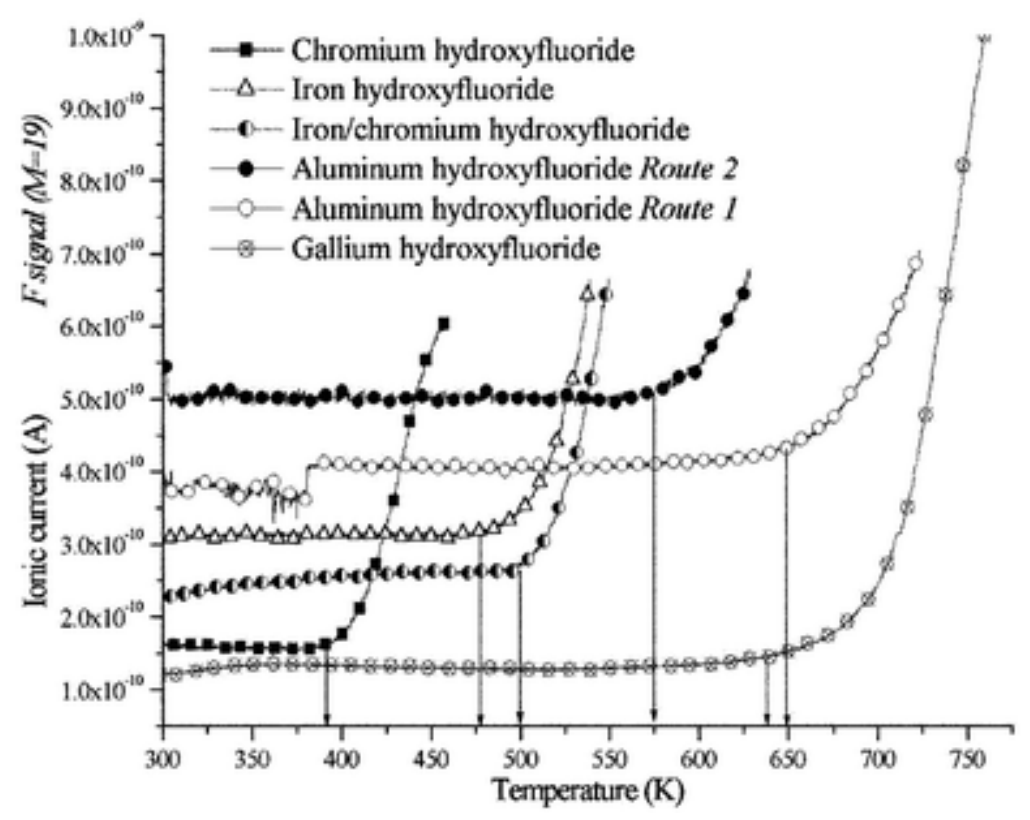

Fig. 7 Comparison of the mass spectrometry patterns $(M=19)$ during the thermogravimetric analysis of the different HTB hydroxyfluorides.

The nature and strength of the surface acidic sites were determined by pyridine adsorption on the surface of the different HTB hydroxyfluoride materials after activation. The IR spectra of samples after pyridine introduction into the cell, present IR bands characteristic of the adsorbed state of the molecule. ${ }_{-}^{20}$ The position and intensity of the ring vibration bands permit the obtainment of information on the nature, strength and concentration of the acid surface sites. Infrared spectra of activated samples (Fig. 8) are recorded after introduction of pyridine into the cell (1 Torr at equilibrium pressure) and a subsequent evacuation at room temperature under secondary vacuum in order to eliminate physisorbed species. In the $1700-1400 \mathrm{~cm}^{-1}$ range, spectra present characteristic bands at 1450 and $1610-1630 \mathrm{~cm}^{-1}$ assigned respectively to $v_{19 \mathrm{~b}}$ and $v_{8 \mathrm{a}}$ modes of pyridine coordinated on Lewis acid sites. The $\beta-\mathrm{FeF}_{3-x}(\mathrm{OH})_{x} \cdot z \mathrm{H}_{2} \mathrm{O}$ sample shows a weaker additional band at 1545 
$\mathrm{cm}^{-1}$, which is characteristic of pyridinium species due to the presence of Brønsted acid sites. The strength of Lewis acid sites is evaluated through the position of the $v_{8 \mathrm{a}}$ mode: the greater the blue shift, the higher the acid strength of the site. After activation at room temperature, $v_{8 \mathrm{a}}$ is observed at $1609 \mathrm{~cm}^{-1}$ for $\beta-\mathrm{FeF}{ }_{3-x}(\mathrm{OH})_{x} \cdot z \mathrm{H}_{2} \mathrm{O}$ and $\beta-\mathrm{Fe}_{0.8} \mathrm{Cr}_{0.2} \mathrm{~F}_{3-x}(\mathrm{OH})_{x} \cdot z \mathrm{H}_{2} \mathrm{O}$, while it is found at $1620 \mathrm{~cm}^{-1}$ for both aluminium hydroxyfluoride samples and at $1618 \mathrm{~cm}^{-1}$ for gallium hydroxyfluoride. This trend in the band position allows us to classify the Lewis acid strength in the hydroxyfluorinated series according to the following sequence:

$$
\beta-\mathrm{AlF}_{3-x}(\mathrm{OH})_{x} \cdot z \mathrm{H}_{2} \mathrm{O}>\beta-\mathrm{GaF}_{3-x}(\mathrm{OH})_{x} \cdot z \mathrm{H}_{2} \mathrm{O}>\beta-\mathrm{FeF}_{3-x}(\mathrm{OH})_{x} \cdot z \mathrm{H}_{2} \mathrm{O} \sim \beta-\mathrm{Fe}_{0.8} \mathrm{Cr}_{0.2} \mathrm{~F}_{3-x}(\mathrm{OH})_{x} \cdot z \mathrm{H}_{2} \mathrm{O}
$$

It should be noticed that it has not been possible to determine the surface acidity of HTB chromium hydroxyfluoride because of a too high amount of adsorbed water at low temperature and the lability of fluorine when the sample is treated under vacuum at high temperature.

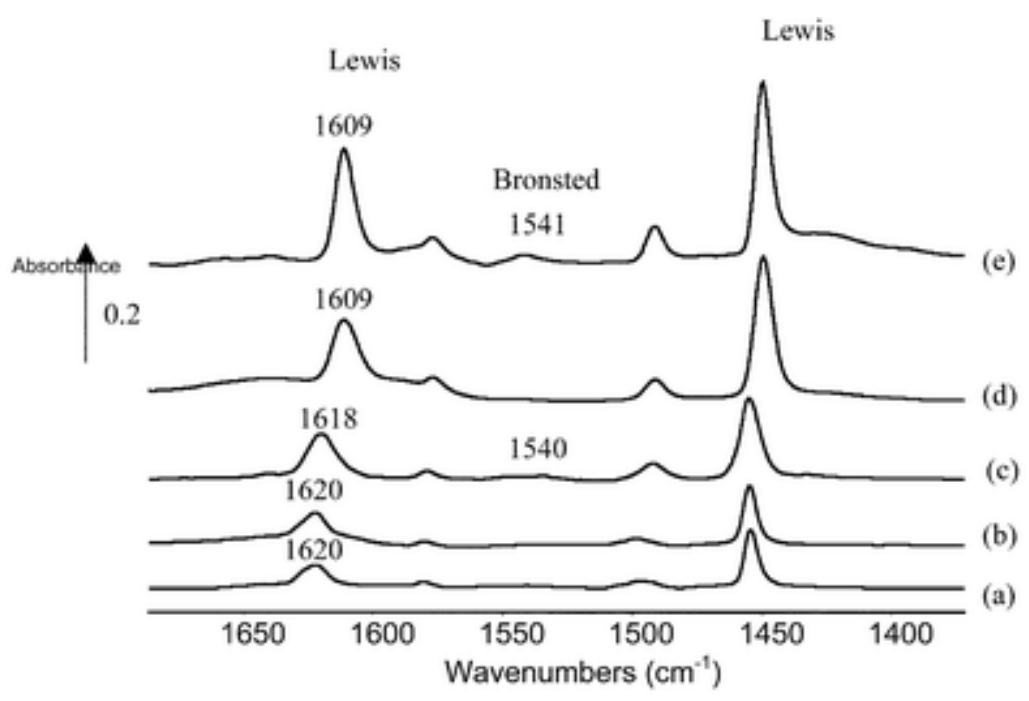

Fig. 8 FTIR spectra of the different HTB hydroxyfluorides after introduction in the cell of $\mathrm{Pe}=1$ torr of pyridine followed by a thermodesorption at RT under vacuum: (a) aluminium hydroxyfluoride route 2 ; (b) aluminium hydroxyfluoride route 1 ; (c) gallium hydroxyfluoride; (d) iron/chromium hydroxyfluoride; (e) iron hydroxyfluoride.

\section{General discussion}

\subsection{Influence of the involved trivalent cation on the final composition}

The presence of hydroxyl groups in these compounds is not surprising. During the growth of metastable HTB forms, fluorination is indeed in competition with hydroxylation. Water molecules are also trapped into the framework. On a thermodynamic aspect, the hydration energies of trivalent aluminium, gallium, iron or chromium cations are equivalent (Table 4). But considering a kinetic point of view, the large amount of water found in chromium hydroxyfluoride comes from the 


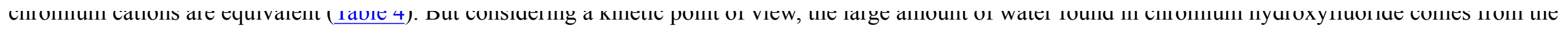
weak lability of water molecules around chromium ions $\left(k\left[\mathrm{Cr}^{3+}\right]=3.10^{-6} \mathrm{~s}^{-1}\right) .{ }_{-}^{23}$ This leads to a difference in the kinetics of the oxolation reaction when compared to the case of trivalent aluminium, gallium or iron. The high stability of the $\mathrm{Cr}\left(\mathrm{H}_{2} \mathrm{O}\right)_{6}{ }^{3+}$ aquo complex can explain both the incomplete outgassing of $\mathrm{HTB}$ chromium hydroxyfluorides and the large particle size distribution. Because of the presence of water molecules in the inner structure, hydrogen bonds are thus created. In $\beta-\mathrm{Fe}_{0.8} \mathrm{Cr}_{0.2} \mathrm{~F}_{3-x}(\mathrm{OH})_{x} \cdot z \mathrm{H}_{2} \mathrm{O}$, the presence of adsorbed water by hydrogen bonds, due to $\mathrm{Cr}^{3+}$ ions, is observed by FTIR $\left(v(\mathrm{OH})\right.$ at around $3150 \mathrm{~cm}{ }^{-1}$ and $\delta(\mathrm{HOH})$ near $1615 \mathrm{~cm}^{-1}$ ) (Fig. 6-b) even after sample desorption at $473 \mathrm{~K}$, while iron hydroxyfluoride appears almost free from water after such a treatment (Fig. 6-a). The presence of water for Cr-containing sample leads also to an agglomeration of thin particles (see Fig. 2-c), which creates a porous volume in the powder and increases consequently the surface area. ( $S \approx 16 \mathrm{~m}^{2} \mathrm{~g}^{-1}$ for iron hydroxyfluoride, and $S \approx 23 \mathrm{~m}^{2} \mathrm{~g}^{-1}$ for iron-chromium hydroxyfluoride in Fig. 4). In the case of iron hydroxyfluoride, because of a faster kinetics of water molecule exchange $\left(k\left[\mathrm{Fe}^{3+}\right]=10^{2} \mathrm{~s}^{-1}\right)$, only a few water molecules stay in the coordination sphere of Fe cohesive hydrogen bonds are fewer and particles are thus smaller.

Table 4 Intrinsic characteristics of $\mathrm{Ga}^{3+}, \mathrm{Al}^{3+}, \mathrm{Fe}^{3+}$ and $\mathrm{Cr}^{3+}$ ions and $\chi / r^{2}$ potential field parameters

\begin{tabular}{|c|c|c|c|c|c|}
\hline Cation $\mathrm{M}^{3+}$ & $\begin{array}{l}\text { Ion } \operatorname{radius} / \AA(\mathrm{CN}= \\
6)\end{array}$ & Electronegativity $\chi$ (Allred-Rochow scale) & $\begin{array}{l}\chi / r^{2}(\mathrm{CN}= \\
6)\end{array}$ & $\begin{array}{l}-\Delta H \text { Hydration energy }{ }_{-}^{23} \\
\text { at } 25^{\circ} \mathrm{C} / \mathrm{kJ} \mathrm{mol}^{-1}\end{array}$ & $\begin{array}{l}\text { Kinetic constant of water } \\
\text { molecule exchange } \text { ex }^{23} / \mathbf{s}^{-1}\end{array}$ \\
\hline $\mathrm{Ga}^{3+}$ & 0.620 & 1.82 & 4.73 & - & - \\
\hline $\mathrm{Al}^{3+}$ & 0.530 & 1.47 & 5.23 & 4700 & 1 \\
\hline $\mathrm{Fe}^{3+}$ & 0.645 & 1.72 & 4.13 & 4450 & $10^{2}$ \\
\hline $\mathrm{Cr}^{3+}$ & 0.615 & 1.59 & 4.20 & 4620 & $3.10^{-6}$ \\
\hline
\end{tabular}

Depending on the involved cation, FTIR spectra have evidenced different kinds of hydroxyl groups, mainly present in the tunnels of the material framework. The weak affinity of trivalent iron for water reduces the tendency for hydroxylation, as currently shown in the case of iron oxides and oxyhydroxydes. ${ }_{-}^{24}$ Consequently, the formation of more fluorinated materials should be favored. That is why just a small amount of linked hydroxyl groups are found in the HTB iron hydroxyfluoride. This trend is also found in the hydroxyfluoride containing both iron and chromium in which two different kinds of free hydroxyl groups and only one kind of linked $\mathrm{OH}$ group are found. The shoulder at $3572 \mathrm{~cm}^{-1}$ should be due to free hydroxyl groups, mainly bound to trivalent chromium, since this feature is only observed in the case of the mixed compound. Moreover, in a first approximation, the covalency of $\mathrm{Cr}-\mathrm{OH}$ bonds is reduced when compared to that of Fe-OH bonds. The difference in electronegativity $\left(\chi\left[\mathrm{Cr}^{3+}\right]<\chi\left[\mathrm{Fe}^{3+}\right]\right)$ accounts for the position of this band at lower wavenumbers with respect to that assigned to hydroxyl species bound to $\mathrm{Fe}^{3+}$ $\left(3595 \mathrm{~cm}^{-1}\right)$, whereas the crystal field stabilization energy $10 \mathrm{Dq}\left(10 \mathrm{Dq}\left[\mathrm{Cr}^{3+}, 3 \mathrm{~d}^{3}\right]>10 \mathrm{Dq}\left[\mathrm{Fe}^{3+}, 3 \mathrm{~d}^{5}\right]\right)$ suggests the opposite.

Aluminium hydroxyfluoride prepared by dehydration of $\mathrm{AlF}_{3} \cdot 3 \mathrm{H}_{2} \mathrm{O}$ (route 2) exhibits only one type of free hydroxyl group which are not located on the external surface of cristallites, as shown by the isotopic exchange. Since these hydroxyl groups can only be partially deuterated by $\mathrm{D}_{2}$ molecules and also because of the reduction of the tunnel size, we can imagine that the HTB one-dimensional tunnels could be partly blocked by a trace of impurities still present in the inner structure even after outgassing. Therefore, the impossibility of $\mathrm{D}_{2} \mathrm{O}$ or water to enter the tunnels limits the hydroxylation process, thus explaining the absence of linked $\mathrm{OH}$ groups in this material. The thermal decomposition of $\left(\mathrm{NH}_{4}\right)_{3} \mathrm{AlF}_{6}$ (route 1) leads to an aluminium hydroxyfluoride containing various hydroxyl groups. Among the 


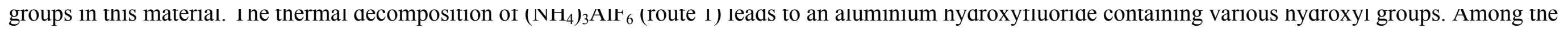
three types of free $\mathrm{OH}$ groups, the IR peak at lower wavenumber is at the same position as that found in the case of route 2 synthesis, so it should be probably be assigned to species located inside the tunnels of the framework. The two other bands at higher wavenumbers are related to free hydroxyl groups on the outer surface of the material which can also be found in $\alpha-\mathrm{AlF}_{3}$, with very similar $\mathrm{OH}$ stretches (Fig. 6-f).

\subsection{Role of the size of HTB tunnels in thermal stability}

The tunnel dimensions of HTB hydroxyfluorides depend on the cation type and on the position of water molecules in the tunnel, as shown in Fig. 9. The volume around the $(0,0,0)$ position determines the lability of water molecules (which are about $1.38 \AA$ large) through the tunnel and consequently their reactivity with fluoride anions. At position $(0,0,0)$, tunnels of about $2.70 \AA$ width have been evidenced in the case of $\beta-\mathrm{FeF}_{3} \cdot 0.33 \mathrm{H}_{2} \mathrm{O} \cdot{ }_{-}^{21} \mathrm{In}$ the case of $\beta-\mathrm{AlF} \mathrm{F}_{3-x}(\mathrm{OH})_{x} \cdot z \mathrm{H}_{2} \mathrm{O}$, the section of the tunnel is narrower, i.e. about $2.42 \AA$. At the position $(0,0,1 / 4)$ the width of the tunnel is about $3.60 \AA$ large for $\beta-\mathrm{FeF}_{3} \cdot 0.33 \mathrm{H}_{2} \mathrm{O}$ and $3.30 \AA$ for $\beta-\mathrm{AlF}_{3-x}(\mathrm{OH})_{x} \cdot z \mathrm{H}_{2} \mathrm{O}$. From an electrostatic point of view, the size of the tunnel is reduced because of the presence of hydrogen bonds between water molecules and hydroxyl groups. It is this interaction which determines the lability of water molecules in the tunnel. Consequently, the lability of water molecules in aluminium hydroxyfluorides is reduced as well as the reactivity of $\mathrm{H}_{2} \mathrm{O}$ with fluoride anions. The thermal stability of aluminium hydroxyfluoride is thus reinforced. Conversely, because of wider tunnels, the lability of $\mathrm{H}_{2} \mathrm{O}$ is raised in iron hydroxyfluoride, and the reactivity of fluorine with hydroxyl groups is increased. The thermal stability of HTB compounds is closely linked to the presence of water in the tunnels because the raising of temperature contributes to an increase in the migration of water molecules through tunnels and to a collapse of the HTB structure. It is thus possible to argue: the smaller the cation, the more stable the structure and the narrower the tunnel, the less reactive the water molecules and the higher the thermal stability.
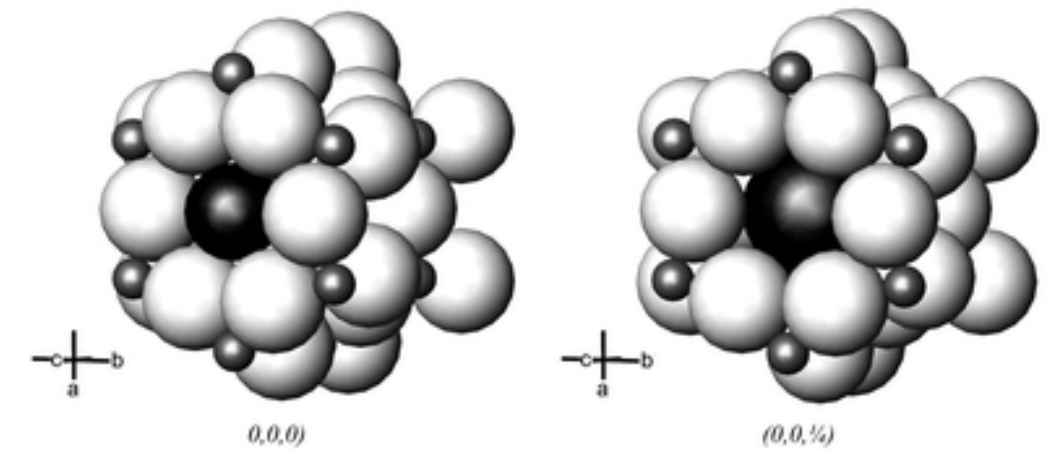

Fig. 9 Size of the tunnels at different crystallographic sites on the HTB structure.

\subsection{Influence of hydroxyl groups and water molecules on the thermal stability: role of the involved trivalent cation}

In order to explain the difference of thermal behavior of HTB-type compounds, in connection with the presence of linked or isolated OH groups, two complementary models can be proposed.

A first model is that under the effect of increasing temperatures, an oxolation reaction would occur between two neighboring linked-OH groups, creating an oxo bridge $\mathrm{M}^{3+}-\mathrm{O}^{2-}-\mathrm{M}^{3+}$, with the departure of $\mathrm{H}_{2} \mathrm{O}$ which is further trapped or not into the tunnels. But the mechanism of oxolation implies a modification of the inner 


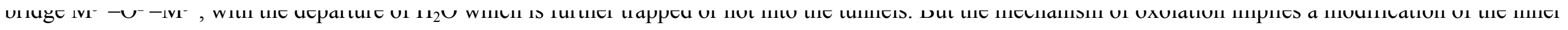

structure due to the formation of these oxo-bridges. It is thus relevant to notice two consequences: i) a modification of the different bounds in the neighborhood of the cations leading to the destabilization of the M-F bonds which must be weakened because of the charge transfer, ii) a lowering of the thermal stability due to the presence of linked OH groups, which are at the origin of HF departure. On the contrary, isolated OH groups would not affect the departure of HF from the inner structure, because they do not undergo oxolation reaction.

If we consider now this problem from a thermodynamic point of view, a complementary model can be proposed. When the oxolation occurs between linked OH groups, the water molecule which is formed is not directly eliminated but can remain within the cation coordination sphere as an aquo ligand. Because fluoride anions are present in the neighborhood of this water molecule and because many oxolation reactions may occur near the fluoride anion, the water partial pressure around fluorine anions increases and then the substitution of $\mathrm{F}^{-}$by $\mathrm{OH}^{-}\left(\mathrm{M}-\mathrm{F}^{-}+\mathrm{H}_{2} \mathrm{O} \rightarrow \mathrm{M}-\mathrm{OH}^{-}+\mathrm{HF}\right)$ may occur. At a given temperature, the equilibrium constant, $K \propto P[\mathrm{HF}] / P\left[\mathrm{H}_{2} \mathrm{O}\right]$, is related to both $\mathrm{H}_{2} \mathrm{O}$ partial pressure and $\mathrm{HF}$ partial pressure in the inner tunnels. An increase in the $\mathrm{H}_{2} \mathrm{O}$ inner pressure displaces the reaction to the right (Le Châtelier law) and yields the formation of HF. Thus, linked OH groups seem to be at the origin of the destabilization of the HTB hydroxyfluorides.

FTIR investigations also enable us to follow the reduction of the content of water molecules (bands around $1650 \mathrm{~cm}^{-1}$ ) trapped in the HTB hydroxyfluoride frameworks at different temperatures, as shown in Fig. 10, as well as the presence of different impurities, such as ammonium ions (ig. 10-e). Whatever the synthesis route, aluminium hydroxyfluoride contains water molecules at $573 \mathrm{~K}$ and the band at $1630 \mathrm{~cm}^{-1}$, that can be still observed at this temperature, can be attributed to water in the tunnels or coordinated to strong Lewis acid sites on the external surface (Fig. 10-a and -b). ${ }_{-}^{25}$ On the contrary, iron hydroxyfluoride does not show water molecules in its tunnels at $473 \mathrm{~K}$ (Fig. 10-c) when HF evolution starts. That could be due to the lower Lewis acidic strength of iron with respect to aluminium, as discussed. In fact it seems that HF begins to evolve as soon as the tunnels have been cleared of water molecules. This result indicates the template effect of water molecules in the HTB structure: surprisingly the presence of $\mathrm{H}_{2} \mathrm{O}$ in the tunnels does increase the thermal stability of these phases, as also noticed by Menz et al. ${ }_{-}^{26}$

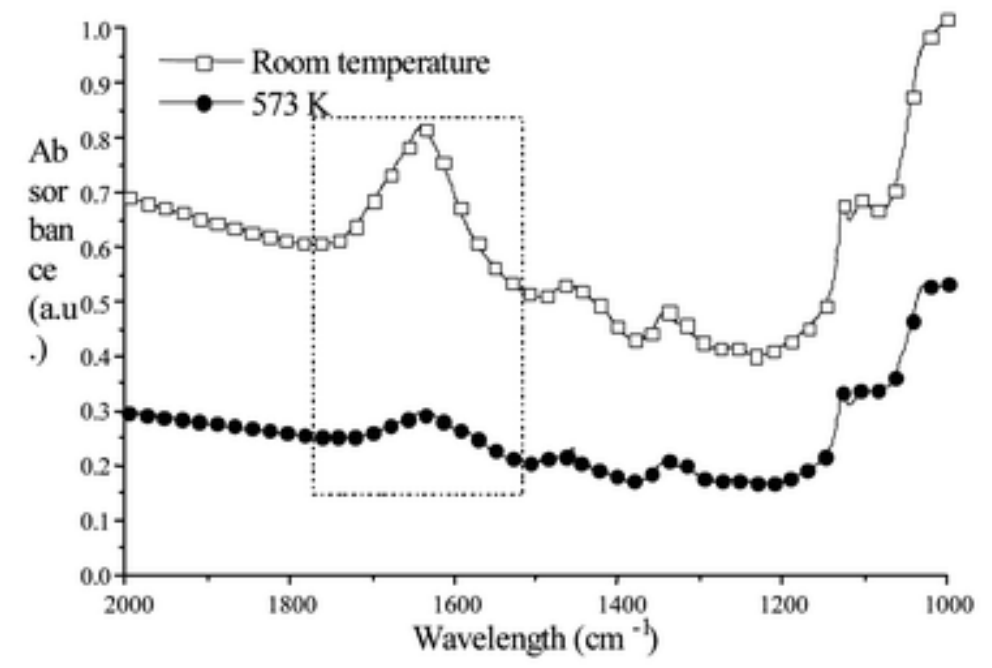

a-Aluminum hydroxyfluoride Route 1.

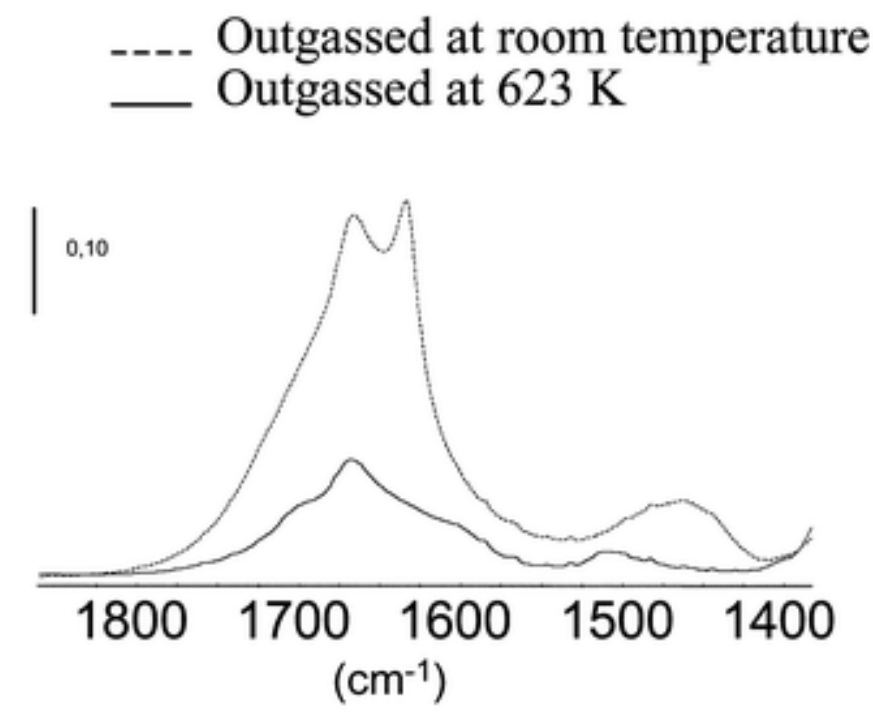

b- Aluminum hydroxyfluoride Route 2. 


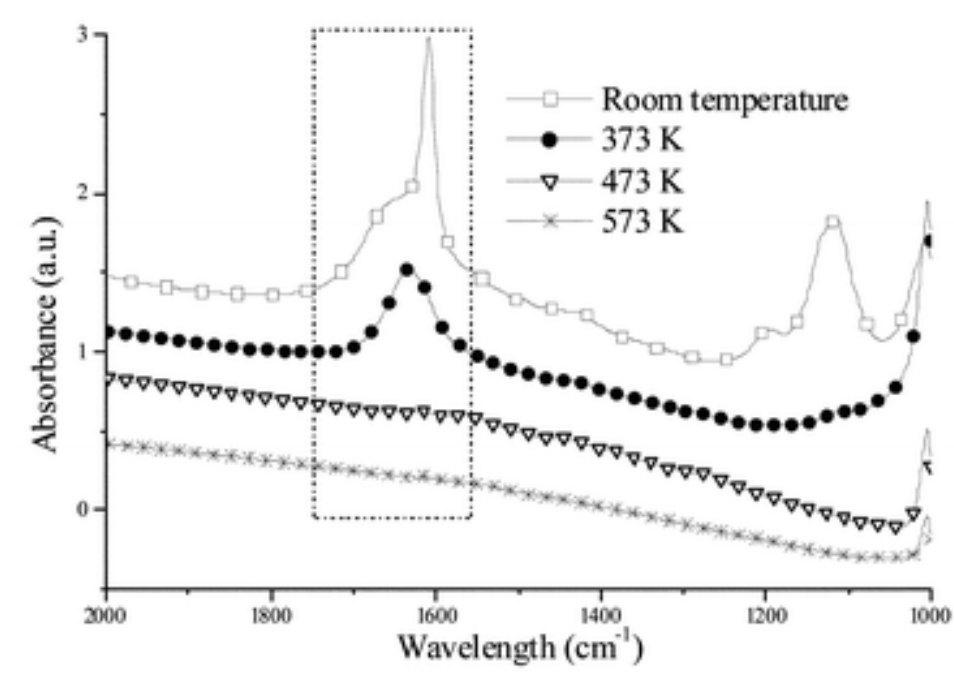

c- Iron hydroxyfluoride.

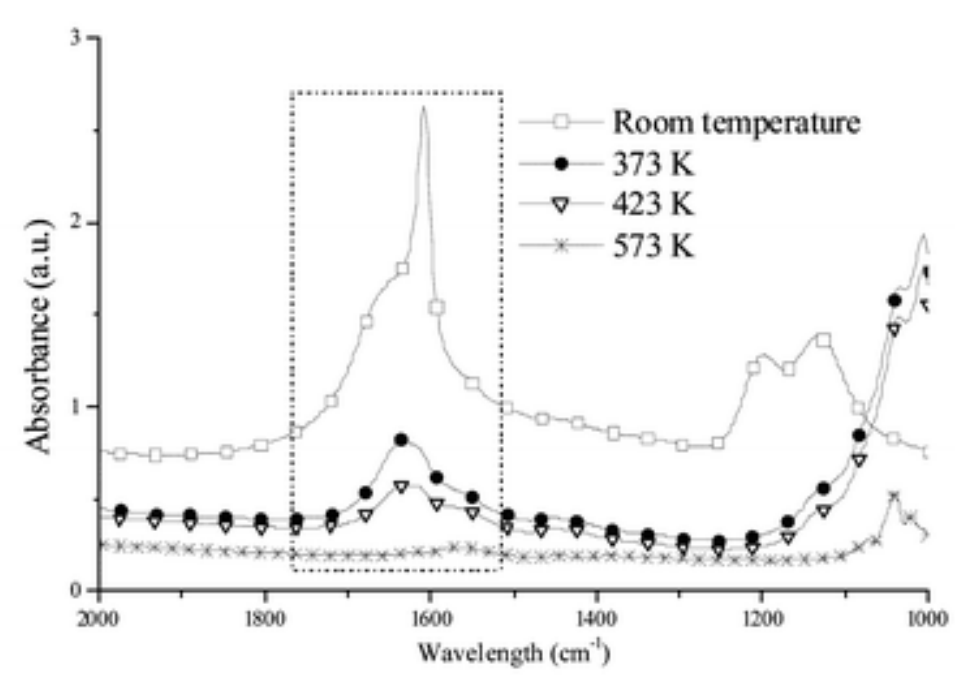

d-Chromium/iron hydroxyfluoride.

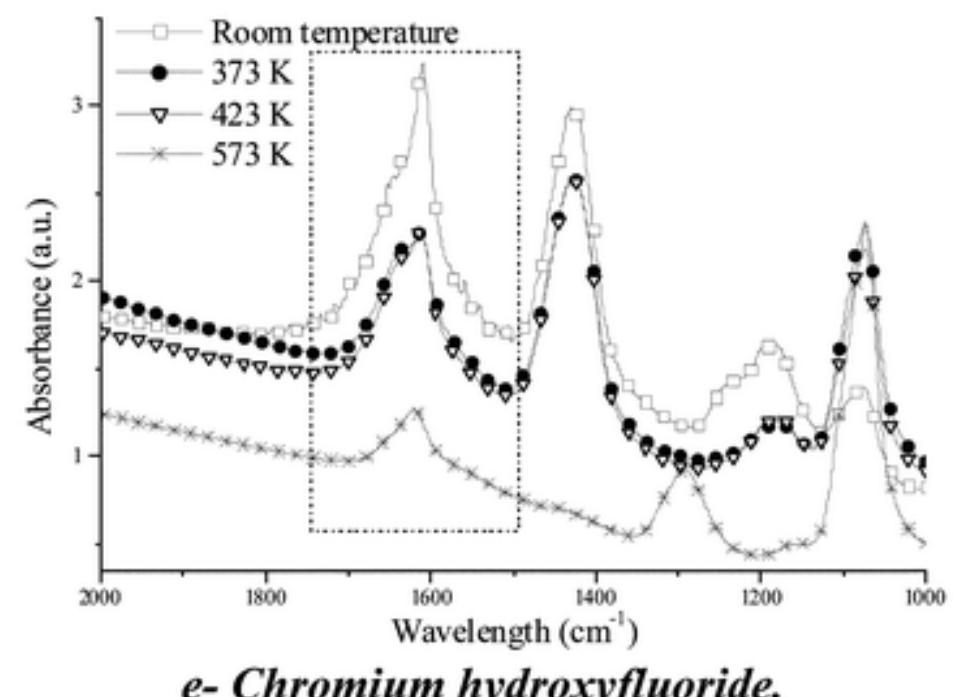

Fig. 10 FTIR spectra of hydroxyfluorides at different temperatures [The dotted box represents the wavenumber range relative to water].

The most unexpected effect is the increase of the thermal stability after a substitution of a small amount of iron cations by trivalent chromium ions (see Fig. 1). Since this material exhibits a surface area higher than homologous pure iron, this effect cannot be related to an extrinsic cause. The difference of water affinity between trivalent chromium and iron ions can explain this trend. On a thermodynamic point of view, water molecules arising from the oxolation reactions have a tendency to be trapped around trivalent iron. But from a kinetic point of view, these water molecules are rapidly exchanged from the iron coordination sphere, contrary to the case of trivalent chromium in which the kinetics of the water molecule exchange is very slow. ${ }_{-}^{23}$ In HTB hydroxyfluoride containing both iron and 
chromium, water molecules which are formed during the oxolation reactions are trapped by chromium cations, with only a small amount of hydroxyl groups remaining around the iron ions. Thus, chromium ions help to increase the thermal stability by keeping water molecules stable into the tunnel of the HTB structure.

\subsection{The electrical field gradient $X \mid r^{2}$ : a relevant parameter to account for both the acidic and thermal properties}

As far as the strength of Lewis acid sites is concerned, ionization energy (IE) and electronegativity $\chi$ are relevant parameters $(\chi=\partial($ IE) $/ \partial q$, Allred-Rochow scale). For the same anion, one should have to consider that in a first approximation the higher the electronegativity, the more acidic is the Lewis acid site. The electronegativity of $\mathrm{Fe}^{3+}\left(\chi\left[\mathrm{Fe}^{3+}\right]=1.72\right)$ remains larger than that of $\mathrm{Al}^{3+}\left(\chi\left[\mathrm{Al}^{3+}\right]=1.47\right)$ and iron hydroxyfluoride should exhibit stronger Lewis acid sites than aluminium hydroxyfluorides.

The stability of the chemical bond depends on the cationic polarizing ability which can be considered, in a first approximation, proportional to the ratio $q / r^{2}$, where $q$ is the effective charge and $r$ is the ionic radius of the cation. Considering aluminium and iron ionic radii $\left(r\left[\mathrm{Al}^{3+}{ }_{(\mathrm{CN}=6)}\right]<r\left[\mathrm{Fe}^{3+}{ }_{(\mathrm{CN}=6)}\right]\right)$, it is not surprising to notice that aluminium hydroxyfluoride exhibits a better thermal stability than iron hydroxyfluoride. However, if trivalent chromium and gallium ionic radii are also considered we should find the following sequence:

$$
r\left[\mathrm{Al}^{3+}{ }_{(\mathrm{CN}=6)}\right]=0.530 \AA<r\left[\mathrm{Cr}^{3+}{ }_{(\mathrm{CN}=6)}\right]=0.615 \AA<r\left[\mathrm{Ga}^{3+}{ }_{(\mathrm{CN}=6)}\right]=0.620 \AA<r\left[\mathrm{Fe}^{3+}{ }_{(\mathrm{CN}=6)}\right]=0.645 \AA
$$

However only considering the ionic radii does not permit an explanation of the thermal stability of HTB hydroxyfluorides and so ionic radii as well as cation electronegativity cannot be used separately to estimate the thermal stability and Lewis acidity of HTB hydroxyfluorides.

Thus another parameter, $\chi / r^{2}$, where $r$ is the ionic radius should be taken into account in order to have a better characterization of both thermal stability and acidic properties (see Table 4). The electronegativity $\chi=\partial(\mathrm{IE}) / \partial q$, in the Allred-Rochow scale is the expression of an electronic chemical potential which depends on the nature of the cation. If a spherical distribution of electronic charges $V(q, r)$ is considered, the $\chi / r^{2}$ parameter can be ascribed to an electrical field gradient around the cation. The $\chi / r^{2}$ magnitude has an influence on the cation direct environment and can be related to both the thermal stability and the acidic properties. If $\chi / r^{2}$ is considered as the decisive parameter, the following sequence can be proposed, which corresponds indeed to the observed trend (see Fig. 7 and the shifts in the $1610-1630 \mathrm{~cm}^{-1}$ range in Fig. 8):

$$
\chi / r^{2}\left[\mathrm{Al}^{3+}\right]>\chi / r^{2}\left[\mathrm{Ga}^{3+}\right]>\chi / r^{2}\left[\mathrm{Cr}^{3+}\right]>\chi / r^{2}\left[\mathrm{Fe}^{3+}\right]
$$

It can be thus concluded that the $\chi / r^{2}$ is a relevant parameter for the classification of the strength of surface acidity and thermal stability in HTB materials. However, it should be noted that the particular affinity of chromium for water molecules decreases the field gradient described by the $\chi / r^{2}$ parameter because of the large amount of water present in its HTB hydroxyfluoride, yielding a very low thermal stability.

\section{Conclusions}

In this paper, our goal was to clarify by a solid state chemistry approach the relationships between the composition, the structural features and some relevant properties of solids that could be considered in heterogeneous catalysis.

In the HTB hydroxyfluorides series, there is competition between the formation of $\mathrm{M}-\mathrm{F}$ and $\mathrm{M}-\mathrm{OH}$ bonds which depends on the type of cation $\left(\mathrm{Al}^{3+}, \mathrm{Cr}^{3+}, \mathrm{Fe}^{3+}\right.$ 
and $\left.\mathrm{Ga}^{3+}\right)$, on the nature of precursor and on the route of synthesis. FTIR spectroscopy studies have allowed to point out that both $\beta-\mathrm{FeF}{ }_{3-x}(\mathrm{OH})_{x} \cdot z \mathrm{H}_{2} \mathrm{O}$ and $\beta-\mathrm{Fe}_{0.8} \mathrm{Cr}_{0.2} \mathrm{~F}_{3-x}(\mathrm{OH})_{x} \cdot z \mathrm{H}_{2} \mathrm{O}$ exhibit free $\mathrm{OH}$ groups and linked $\mathrm{OH}$ groups. Aluminium hydroxyfluoride prepared by thermal dehydration of $\mathrm{AlF}_{3} \cdot 3 \mathrm{H}_{2} \mathrm{O}$ exhibits free hydroxyl groups only, whereas the degradation of $\left(\mathrm{NH}_{4}\right)_{3} \mathrm{AlF}_{6}$ leads to additional types of free hydroxyl groups and linked hydroxyl groups.

Depending on the nature of the cation, the decomposition kinetics of $\mathrm{M}\left(\mathrm{H}_{2} \mathrm{O}\right)_{6}{ }^{3+}$ aquo complex and the size of tunnels in the HTB framework determine the amount and the nature of $\mathrm{H}_{2} \mathrm{O} / \mathrm{OH}$ groups detected in these compounds. For instance, the comparison between $\mathrm{Al}^{3+}$ and $\mathrm{Fe}^{3+}$ hydroxyfluorides shows a difference in the size of the tunnels in their respective HTB structure. It has been proposed that the ratio of linked to free hydroxyl groups, as well as water trapped inside the framework, which has been detected by FTIR, may explain the difference in thermal stability of these solids. The nature of hydroxyl groups is closely linked to the involved trivalent cation but also to the nature of the precursors and the route of synthesis. The template effect of water has been underlined. The nature of cations,

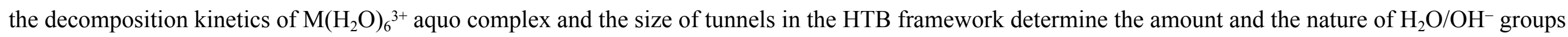
present in these compounds. For instance, the comparison between $\mathrm{Al}^{3+}$ and $\mathrm{Fe}^{3+}$ hydroxyfluorides shows that the $\mathrm{Al}-(\mathrm{F}, \mathrm{OH})$ bond is more stable than the $\mathrm{Fe}-(\mathrm{F}, \mathrm{OH})$ one, with a difference of more than $200 \mathrm{~K}$ in their thermal stability. The presence of a large amount of free $\mathrm{OH}^{-}$groups around $\mathrm{Al}^{3+}$ contributes also to a better thermal stability. The substitution or $\mathrm{Fe}^{3+}$ by $\mathrm{Cr}^{3+}\left(\left[\mathrm{Cr}^{3+}\right] /\left[\mathrm{Fe}^{3+}\right]<25 \%\right)$ which gives rise to an increase of the content of $\mathrm{H}_{2} \mathrm{O} / \mathrm{OH}_{\text {groups }}$ preferentially around $\mathrm{Cr}^{3+}$, allows the improvement of the $\mathrm{M}-\mathrm{F}$ bonding stability. On the other hand, the large amount of water and linked hydroxyl groups trapped around $\mathrm{Cr}^{3+}$ in pure chromium hydroxyfluoride contributes to its destabilization by the creation of oxo bridges $\mathrm{M}-\mathrm{O}-\mathrm{M}$ with the formation of water and HF. This particular affinity of chromium for water also accounts for the change in morphology of the powder.

Finally, the acidic character of these solids has been evaluated by FTIR analysis using probe molecule adsorption and leads to the conclusion that the strongest Lewis acidity is found in $\mathrm{Al}^{3+}$ and $\mathrm{Ga}^{3+}$ homologous compounds. These characteristics can be directly related to the strength of the $\mathrm{M}-(\mathrm{F}, \mathrm{OH}) \mathrm{chemical}$ bond and the thermal stability of these solids. The use of the ratio $\chi / r^{2}$ between the electronegativity $\chi$ and the ionic radius $r$, which can be assigned to an electrical field gradient around the cation, has been proposed to explain some important trends in this series. This parameter allows an original approach of both the acidic strength and the thermal stability and accounts for the experimentally observed sequence, which was not the case when either ionic radius or cation electronegativity was considered separately. The effectiveness of this $\chi / r^{2}$ parameter will be tested on another series of materials.

\section{Acknowledgements}

We thank Rhodia company for financial support and A. Seigneurin and P. Maestro for constant interest. E. Kemnitz, from the Humboldt University of Berlin (Germany) is acknowledged for fruitful discussions and suggestions on the properties of HTB hydroxyfluorides. Finally we thank M. Leblanc (LDF, Université du Maine, France) whose knowledge on HTB phases has been very valuable.

\section{References}

1. J. M. Thomas, J. Chem. Soc., Dalton Trans., 1991, 555 RSC U >Accéder

2. J. A. Rabo and G. J. Gadja, Catal. Rev., 1989-1990, 31, 385 Search PubMed U >Accéder . 
3. A. K. Ghosh and R. A. Kydd, Catal. Rev. Sci. Eng., 1985, 27(4), 539 Search PubMed U > Accéder

4. J. M. Saniger, N. A. Sánchez and J. O. Flores, J. Fluorine Chem., 1998, 88, 117 CrossRef CAS U > Accéder

5. P. O. Scokart and P. G. Rouxhet, J. Colloid Interface Sci., 1982, 86, 96 CAS U >Accéder

6. E. Kemnitz, A. Kohne, I. Grohmann, A. Lippitz and W. E. S. Unger, J. Catal., 1996, 140, 270 CrossRef CAS U > Accéder .

7. Y. S. Shung, H. Lee, H. D. Jeong, Y. K. Kim, H. G. Lee, H. S. Kim and S. Kim, J. Catal., 2000, 175, 239 U >Accéder .

8. N. Herron and W. E. Farneth, Adv. Mater., 1996, 8(12), 959 CrossRef CAS U >Accéder .

9. E. Kemnitz and D. H. Menz, Prog. Solid State Chem., 1998, 26, 97 CrossRef CAS U >Accéder .

10. E. Kemnitz and J. M. Winfied, in: Advanced Inorganic Fluorides: Synthesis, Characterization and Applications, eds. T. Nakajima, B. Žemva, A. Tressaud,

Elsevier, 2000, 367 Search PubMed U > Accéder.

11. E. Kemnitz, Y. Zhu and B. Adamczyck, J. Fluorine Chem., 2002, 114, 163 CrossRef CAS U > Accéder .

12. A. Demourgues, L. Francke, E. Durand and A. Tressaud, J. Fluorine Chem., 2002, 114(2), 229-236 CrossRef CAS U >Accéder .

13. N. Herron, D. L. Thorn, R. L. Harlow, G. A. Jones, J. B. Parise, J. A. Fernandez-Baca and T. Vogt, Chem. Mater, 1995, 7(1), 75 CrossRef CAS U >Accéder .

14. A. Le Bail, C. Jacobini, M. Leblanc, R. de Pape, H. Duroy and J. L. Fourquet, J. Solid State Chem., 1988, 77, 96 CrossRef CAS U >Accéder .

15. D.-H. Menz, J. Therm. Anal., 1992, 38, 321 Search PubMed U > Accéder .

16. B. Adamczyk, A. Hess and E. Kemnitz, J. Mater. Chem., 1996, 610, 1731 RSC U >Accéder .

17. A. Hess, E. Kemnitz, A. Lippitz, W. E. S. Unger and D.-H. Menz, J. Catal., 1994, 148, 270 CrossRef U >Accéder .

18. L. K. Beck, B. Haendler-Kruger and H. M. Haendler, J. Solid State Chem., 1973, 8, 312 CAS U >Accéder .

19. F. Seel, Angew. Chem., 1964, 76, 532 CAS U >Accéder .

20. E. Payen, J. Grimblot, J. C. Lavalley, M. Daturi and F. Maugé, Handbook of Vibrational Spectroscopy, ed. J. M. Chalmers and P. R. Griffith, vol. 4, Wiley, New York, 2001 Search PubMed U >Accéder.

21. M. Leblanc, G. Ferey, P. Chevalier, Y. Calage and R. de Pape, J. Solid State Chem., 1983, 47, 53 CAS U >Accéder .

22. G. Ferey and J. Pannetier, Eur. J. Solid State Inorg. Chem., 1994, 31, 697 CAS U >Accéder .

23. F. Basolo and R. G. Pearson, Mechanism of Inorganic Reactions, 2nd edn., J. Wiley and Sons, New York, 1958 Search PubMed U >Accéder .

24. J. P. Jolivet, De la solution à l'oxyde, Inter Ed. \& CNRS Ed., Paris, 1994 Search PubMed U >Accéder .

25. C. H. Barclay, H. Bozorgzadeh, E. Kemnitz, M. Nickkho-Amiry, D. E. M. Ross, T. Skapin, G. Webb and J. M. Winfield, J. Chem. Soc, Dalton Trans., 2002, 40 RSC U > Accéder.

26. D. H. Menz, C. Mensing, W. Hönle and H. von Schnering, Z. Anorg. Allg. Chem., 1992, 611, 107 CrossRef CAS U >Accéder . 